\title{
Morphological and molecular taxonomy of Dendrolimus sibiricus Chetverikov stat.rev. and allied lappet moths (Lepidoptera: Lasiocampidae), with description of a new species
}

\author{
Kauri Mikkola \& Gunilla Ståhls
}

\begin{abstract}
Mikkola, K. \& Ståhls, G. 2008: Morphological and molecular taxonomy of Dendrolimus sibiricus Chetverikov stat.rev. and allied lappet moths (Lepidoptera: Lasiocampidae), with description of a new species. — Entomol. Fennica 19: 6585.
\end{abstract}

The populations of the well-known forest pest, Dendrolimus sibiricus Chetverikov, 1908 stat.rev., were sampled in the European foothills of the Ural Mountains, Russia. D. sibiricus is a species distinct from the Japanese taxon $D$. superans (Butler, 1877). Another taxon from the Southern Urals, taxonomically close to $D$. pini (Linnaeus), is described here as D. kilmez sp.n. The synthetic female pheromones prepared for $D$. pini and $D$. sibiricus attracted equally well all three taxa present, and thus cannot be used to identify these species. The Ural populations of $D$. sibiricus show differences in external appearance, and as already in the 1840s Eversmann indicated that the species had caused local forest damage, D. sibiricus must be a long-established species in the Ural area. Thus, natural spreading westward of the pest is not to be expected. The five Dendrolimus species of the northern Palaearctic and the male genitalia are illustrated, and the distinguishing characters are listed. Two Matsumura lectotypes are designated.

K. Mikkola, Finnish Museum of Natural History, P.O. Box 17, FI-00014 University of Helsinki, Finland; E-mail: kauri.mikkola@helsinki.fi

G. Ståhls, Finnish Museum of Natural History, P.O. Box 17, FI-00014 University of Helsinki,Finland; E-mail: gunilla.stahls@helsinki.fi

Received 8 January 2008, accepted 26 April 2008

\section{Introduction}

In Russia, in 1977-1998, the annual forest damage caused by the caterpillars of the Siberian pine-tree lappet or Siberian silk moth, Dendrolimus sibiricus Chetverikov, 1908, averaged 150,000 hectares (variation 5,600 to 574,800 ha; Gninenko 2000; cf. Kharuk et al. 2004). The forest losses that occurred in the early 1900's on the island of Sakhalin were described as spectacular (Matsumura 1925, Kuznetsov 2006). In recent years, species of Dendrolimus have been particularly serious pine forest pests also in China (Zhang et al. 2004).

Chetverikov (1903) and Petersen (1905) reported damage caused by the caterpillars of $D$. sibiricus in the southeastern parts of the Ural Mountains. They noted that the species has, according to the foresters, invaded the Urals from the east. Petersen forecasted it to spread "in the nearest future" into Europe. This view of recent spreading from the east and expected continued 
spreading westward is maintained by several Russian authors (e.g. Gninenko 2000, Orlinskiy 2000, Konefal \& Karnkowski 2003). However, Eversmann (1844) indicated that the pest was present in the Ural area around 60 years before the notes of Chetverikov and Petersen (see below). Gninenko \& Orlinskiy (2002) report the westernmost occurrences as being in western Udmurtia, where forest damage occurred in the late 1950s. More recent defoliation has been observed in Perm (A.N. Omysheva, oral comm.).

The closely related Japanese species $D$. superans (Butler, 1877) is also a pest on coniferous trees (Maeto 1991). The damage caused by the European pine-tree lappet D. pini (Linnaeus, 1758) is less dramatic (e.g. Möller 2005). Ebert (1994) gave only historical data about defoliations by this species in SW Germany. Saalas (1949) mentioned forest damage in Norway in 1812-1816 and 1902, and Sweden in 1938-1940, but not at all in Finland. Wellenstein (1978) reported no forest damage in Europe since 19471948.

The most recent taxonomic revision of the genus Dendrolimus is by Lajonquière (1973), who recognized 12 species, all from the Palaearctic region. Most taxonomists have considered, following Lajonquière, the Siberian taxon as a subspecies of the Japanese taxon D. superans, and used the combination Dendrolimus superans sibiricus (e.g. Dubatolov \& Zolotuhin 1992, Zolotuhin 1995, Chistyakov 1999). This combination was also adopted by a Russian handbook on forest pest dynamics (Isayev et al. 2001: 290), by several Russian researchers (Gninenko 2000, Kirichenko \& Baranchikov 2004) and by the Canadian Food Inspection Agency (2005). However, the CABI (1996) list and the European Plant Protection Organization (EPPO 2002, 2005) have followed "the main international opinion" (!) and use the name $D$. sibiricus Chetverikov, as do some Russian scientists (e.g. Gninenko \& Orlinskiy 2002) and some other forest pest researchers (e.g. Økland et al. 2004). Thus, there is "significant disagreement about the true identity of the species and its proper scientific name" (Davis et al. 2005).

The 'Ural Mts.' is one of the type localities of D. sibiricus (Chetverikov 1908), as soon noted by Grünberg (1911). Gaede (1932) was the first to il- lustrate the species. Useful morphological characters distinguishing the European pine-tree lappet D. pini and the Siberian taxon have, as far as we know, never been published.

The distribution of $D$. sibiricus on the European side of the Ural Mts. is particularly poorly documented. The scientific collections of the MGU (Moscow State University) and ZIN (Zoological Institute of Russian Academy of Science, St Petersburg) to our knowledge do not hold any materials of Dendrolimus from the Ural area. A field guide to the European "Bombyces" (Rougeot \& Viette 1980) and a handbook treating, e.g., the Western Palaearctic Lasiocampidae (de Freina \& Witt 1987) do not mention the taxon at all. A handbook of forest pests (Wellenstein 1978) expressly notes that the species does not occur in Europe.

Gninenko \& Orlinskiy (2002) claim widespread occurrence of $D$. sibiricus in the Republic of Mari El, between Moscow and the Ural Mts. This could not be confirmed by the field collections made in Mari El by the author KM in 1997 nor by the Finnish monitoring scheme "Nocturna" (cf. Nieminen 1996) in 1998 and 1999. The claim about the occurrence of the Siberian taxon in Mari El and in the Moscow and Tver regions (Gninenko \& Orlinskiy 2002) may be based on an erroneous concept of species specificity of the synthetic female pheromones used to attract males (cf. Pletniev et al. 1999).

To facilitate determination of the quarantine status of $D$. sibiricus by the European and Mediterranean Plant Protection Organization (EPPO), an expedition to the low foothills of the Ural Mts., to Perm and Udmurtia, was funded by the Finnish Plant Protection Department (KTTK). The trip was made in cooperation with the Russian quarantine authorities of these regions.

The field collections also aimed at obtaining specimens of Dendrolimus for molecular work. Previous DNA studies on Dendrolimus spp. concern microsatellite variation of eight Chinese species and subspecies (Zhang et al. 2004), and are not informative for the present study. MtDNA is particularly useful for species-level analyses, as demonstrated in many studies of insect evolutionary relationships. We employed mitochondrial COI (cytochrome $c$ oxidase subunit I) sequences of the 3 ' and 5' regions (from our laboratory and 
from the Barcoding of Life laboratory in Canada, respectively) in conjunction with DNA characters from the nuclear ITS2 (second internal transcribed spacer) gene region.

The aim of the present study is to 1) stabilize the nomenclature of the Siberian taxon, 2) describe distinguishing morphological characters for all five Dendrolimus species that occur in the northern latitudes of the Palaearctic region, and 3) use DNA sequence data to augment the morphological taxonomy. Thus, we employ the concept of integrative taxonomy by using traditional morphological characters in addition to modern techniques of eversion of internal genitalia (cf. Mikkola 2007, 2008), and by combining DNA data from multiple sources with the morphological material and interpreting the produced data in light of available information about species distributions.

\section{Material and methods}

\subsection{Collections}

On 1.-15.VII.2002, samples of D. sibiricus were collected from two coniferous forests, in Perm (at $60^{\circ} 30^{\prime} \mathrm{N} 56^{\circ} 20^{\prime} \mathrm{E}$, ca. $50 \mathrm{~km} \mathrm{NW}$ of Cherdyn) and about $500 \mathrm{~km} \mathrm{SW}$ of Cherdyn, in Udmurtia (at $57^{\circ} 00^{\prime} \mathrm{N} 51^{\circ} 05^{\prime} \mathrm{E}$, outskirts of Kilmez, cf. Fig. 1), both sites in the lowland-like western foothills of the Ural Mountains. In both forests, Abies sibirica grew together with Picea abies and Pinus silvestris.

The following collecting methods were used: (1) two portable light traps equipped with $125 \mathrm{~W}$ mercury vapour bulbs, run by a $1 \mathrm{~kW}$ Honda generator, and (2) female pheromones for $D$. pini and D. sibiricus, prepared in the Netherlands (Pherobank) and in Russia (cf. Pletniev et al. 1999, Klun et al. 2000), respectively. The former were used in commercial glue traps, the latter in Finnish-designed bait traps.

By running light traps, 10 and 21 males of Dendrolimus were collected at Cherdyn ( $D$. sibiricus) and Kilmez (D. sibiricus and sp.), respectively. In addition, the pheromone traps collected several dozen males. Because of the glue and erratic flying in the bait traps, these specimens were mostly in weak condition and used

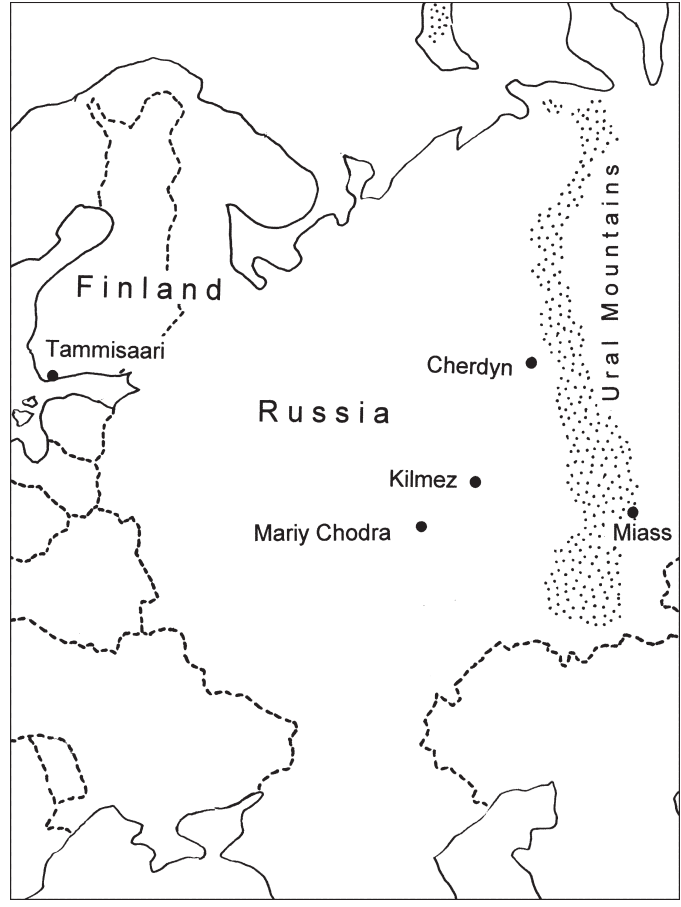

Fig. 1. Sampled localities in Russia and Finland.

mainly for sequencing. We also sequenced a caterpillar of $D$. sibiricus donated by B.I. Kovalev.

Comparative samples of moths were obtained from Tammisaari, Finland (KM, D. pini), from Mari El, Mariy Chodra (KM, D. pini and sp.), from Miass, Chelyabinsk region, southeastern Ural area (K. Nupponen and M. Ahola, D. sibiricus, pini and sp.), from Primorye, the Russian Far East (V. S. Kononenko, D. sibiricus) and from Japan (several sites; M. Owada and associates, $D$. superans and spectabilis) as well as from museum materials collected earlier in Siberia [mainly Altai Mts. and Buryatia; Finnish Museum of Natural History (MZH), D. sibiricus], All specimens in the illustrations are, if not otherwise indicated, from the MZH.

\subsection{Morphological studies}

The morphological distinction of the taxa is based on male genitalia; only single females of $D$. pini and D. sibiricus were dissected. Microscopic genitalia slides were prepared by conventional methods, but the male vesicae and the female 


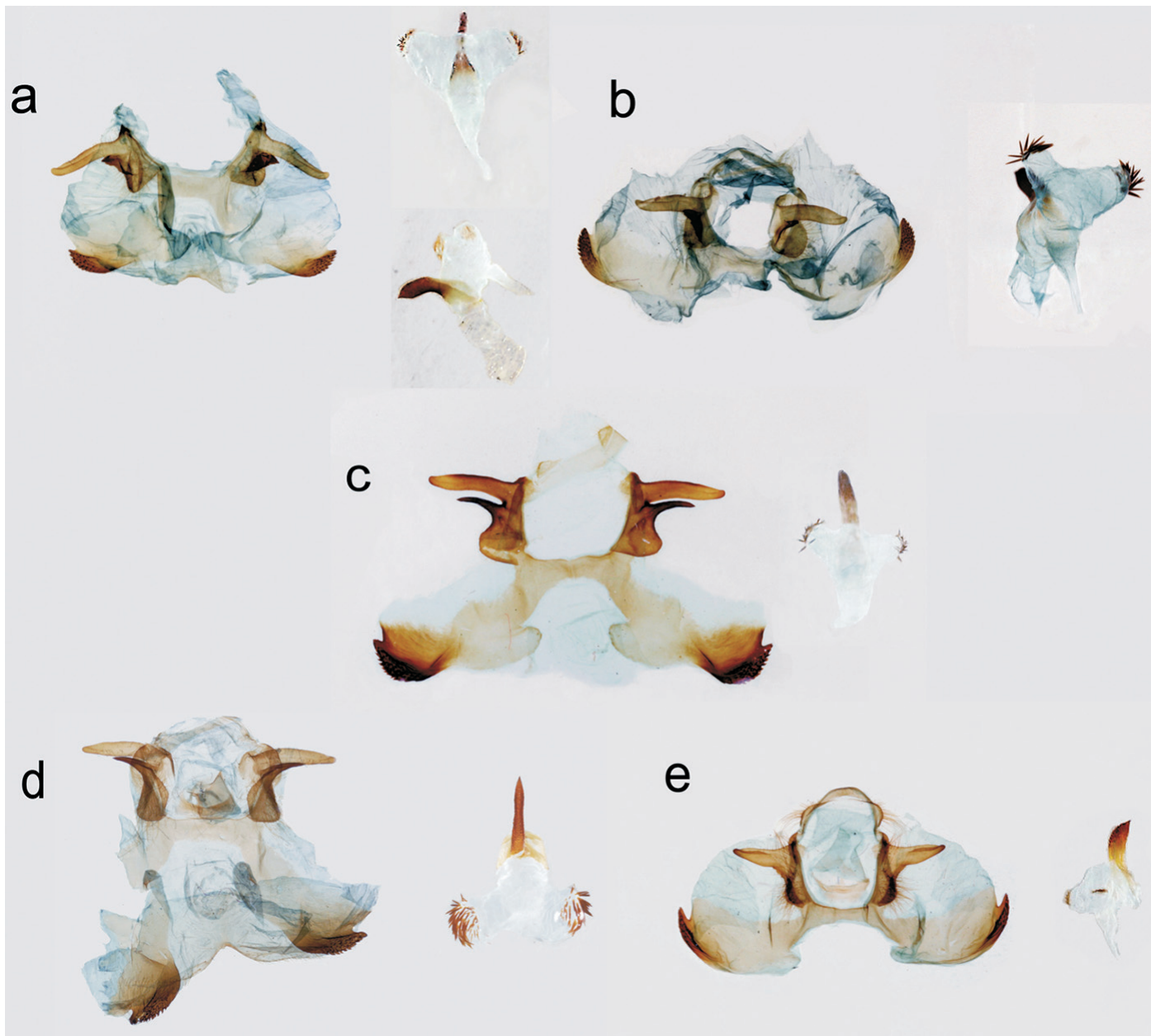

Fig 2. The male genitalia of five species of Dendrolimus, to the left, the opened external genitalia and, to the right, the everted vesica, photographed in vitro. - a. D. pini, showing vesica also in a lateral view (lower figure). - b. D. kilmez sp. n. - c. D. sibiricus. - d. D. superans. - e. D. spectabilis.

bursae were first stained using chlorazol black and then everted using isopropyl alcohol injections with a syringe. A number of vesicae that are highly three-dimensional were, before mounting them on slides, photographed in vitro (Fig. 2). When molecular and morphological differences between $D$. sibiricus and $D$. superans as well as between $D$. pini and $D$. sp. had been detected, more males of each taxon were dissected and sequenced; the observed differences remained constant. To construct a Hennigian argumentation scheme, the keys must be consulted.

\subsection{Molecular methods}

We first produced nucleotide sequences of the 3' fragment of mitochondrial COI and the nuclear ITS2 gene regions from specimens that, based on external morphology, were identified as $D$. pini, $D$. sibiricus and D. superans, and from specimens of D. spectabilis and Lasiocampa trifolii (Denis $\&$ Schiffermüller) as outgroups. For comparison, P. Hebert (Guelph, Canada) kindly provided sequences of the COI-5' fragment generated from five of our sequenced specimens, and from five additional specimens provided by us.

DNA was extracted usually from 2-3 legs of 
specimens preserved in 70-95\% alcohol or from relatively fresh pinned museum specimens (Table 1). DNA was extracted using the Nucleospin Tissue Kit (Machery-Nagel, Düren, Germany) according to manufacturer's protocols. The moths were preserved as DNA voucher specimens in the Zoological Museum (MZH) of the Finnish Museum of Natural History (FMNH), Helsinki, Finland. DNA voucher specimens carry labels, including labcodes and locality information, as indicated in Table 1 .

PCR and sequencing procedures followed those described in Mengual et al. (2006). The primers used for amplifying and sequencing for the COI were C1-J-2183 (alias Jerry, 5'CAACATTTATTTTGATTTTTTGG-3') and t12-n-3014 (alias Pat, 5'-TCCAATGCACTAATCTGCCATATTA-3') (Simon et al. 1994) and for the ITS2 fragment ITS2A 5'-TGTGAACTGCAGGACACAT-3' and ITS2B 5'-TATGCTTAAATTCAGGGGGT-3' (Beebe \& Saul 1995). The sequences were edited and assembled using Sequence Navigator ${ }^{\mathrm{TM}}$ (version 1.01).

In a preliminary parsimony analysis of ITS2 sequences, we used Dendrolimus punctatus (Walker, 1855) (China; data from GenBank) as an outgroup, but since D. spectabilis (Japan; EMBL accession number AJ577260) as an outgroup produced an identical topology, only the latter is shown. We could not amplify the ITS2 fragment for Lasiocampa trifolii (SW Finland) or the COI3' fragment for D. spectabilis. Hence, we were forced to construct the cladograms using different outgroups, and we did not combine ITS2 and COI sequences. The COI-5' fragment could be amplified for $D$. spectabilis apparently due to sufficiently universally conservative primers, as opposed to the primer sites of the COI-3' fragment (Hebert \& Lafontaine, pers. comm.). Thus, $D$. spectabilis was used as outgroup in the ITS2 matrix and in the COI-5' dataset, and L. trifolii in the COI-3' data set.

The COI-3' fragment comprised 729 nucleotides for 29 ingroup specimens (see Table 1 for GenBank accession numbers), and we obtained the COI-5' sequences of $658 \mathrm{nt}$ for 10 ingroup specimens. The latter were obtained for two specimens each of $D$. sibiricus, $D$. superans and $D$. kilmez sp.n., and for four specimens of D. pini. As we had only five specimens from which both COI sequence fragments were achieved, we had no reason to combine the data sets.

Our pruned data matrix of the ITS2 region comprised 31 ingroup specimens and four outgroup specimens with sequence length variation of 473-478 nt among ingroup taxa. The aligned ITS2 sequence matrix comprised $484 \mathrm{nt}$ characters.

\subsection{Parsimony analyses}

Analyses of the ITS2, COI-3' and COI-5' sequence matrices were conducted using the parsimony program NONA v. 2.0 (Goloboff 1998) spawn from Winclada (Nixon 1999), with the command line "hold 100000; hold/50, mult* 1000 ; $\max ^{*}$. All characters were equally weighted, and gaps were treated as fifth character states in the ITS2 analysis. To illustrate and describe COI haplotype diversity among included specimens, sequences were manually compared and variable nucleotide positions were documented.

\subsection{Pheromone studies}

Experiments using female pheromones manufactured for D. pini and D. sibiricus (The Netherlands, Pherobank, and Krasnoyarsk, see Klun et al. 2000, respectively) were conducted in the field in Perm and Udmurtia, Russia, and at Tammisaari, Finland.

\section{Results}

Our results confirm the occurrence of the Siberian taxon $D$. sibiricus on the European side of the Ural Mts., and we re-examine its history there as well as separate it taxonomically from the Japanese $D$. superans, and describe a new sister species of $D$. pini from the southern parts of the Ural Mts. 
Table 1. List of Dendrolimus and Lasiocampa trifolii specimens used for molecular study, including GenBank (GB) accession numbers.

\begin{tabular}{|c|c|c|c|}
\hline Lab code & Taxon & $\begin{array}{l}\text { Locality } \\
\text { Date, Collector }\end{array}$ & $\begin{array}{l}\text { GB acc. COI } \\
\text { GB acc. ITS2 }\end{array}$ \\
\hline $\mathrm{MZH}$ KMM1 & D. sibiricus Chetverikov, 1908 & $\begin{array}{l}\text { Russia, Perm, Cherdyn, } \\
\text { 5.-6.VII.2002, K. Mikkola leg. }\end{array}$ & $\begin{array}{l}\text { AM946694 } \\
\text { AM946744 }\end{array}$ \\
\hline MZH_KM2 & D. sibiricus Chetverikov, 1908 & $\begin{array}{l}\text { Russia, Perm, Cherdyn } \\
\text { 5.-6.VII.2002, K. Mikkola leg. }\end{array}$ & $\begin{array}{l}\text { AM946695 } \\
\text { AM946745 }\end{array}$ \\
\hline MZH_KM3 & D. sibiricus Chetverikov, 1908 & $\begin{array}{l}\text { Russia, Perm, Solikamsk, } \\
\text { Kovalev leg., } 2002\end{array}$ & $\begin{array}{l}\text { AM946696 } \\
\text { AM946746 }\end{array}$ \\
\hline $\mathrm{MZH}$ & D. kilmez sp.n. & $\begin{array}{l}\text { Russia, Udmurtia, Kilmez, } \\
\text { 8.VII.2002, K. Mikkola leg. }\end{array}$ & $\begin{array}{l}\text { AM946707 } \\
\text { AM946727 }\end{array}$ \\
\hline $\mathrm{MZH}$ & D. sibiricus Chetverikov, 1908 & $\begin{array}{l}\text { Russia, Udmurtia, Kilmez, } \\
\text { 8.VII.2002, K. Mikkola leg. }\end{array}$ & $\begin{array}{l}\text { AM946697 } \\
\text { AM946756 }\end{array}$ \\
\hline MZH_KM6 & D. sibiricus Chetverikov, 1908 & $\begin{array}{l}\text { Russia, Udmurtia, Kilmez, } \\
\text { 8.VII.2002, K. Mikkola leg. }\end{array}$ & AM946698 \\
\hline $\mathrm{MZH}$ KKM7 & D. sibiricus Chetverikov, 1908 & $\begin{array}{l}\text { Russia, Perm, Cherdyn, } \\
\text { 4.VII.2002, K. Mikkola leg. }\end{array}$ & AM946747 \\
\hline MZH_KM8 & D. sibiricus Chetverikov, 1908 & $\begin{array}{l}\text { Russia, Perm, Cherdyn, } \\
\text { 4.VII.2002, K. Mikkola leg. }\end{array}$ & AM946748 \\
\hline $\mathrm{MZH}$ KM9 & D. sibiricus Chetverikov, 1908 & $\begin{array}{l}\text { Russia, Perm, Cherdyn, } \\
\text { 4.VII.2002, K. Mikkola leg. }\end{array}$ & AM946699 \\
\hline MZH_KM12 & D. sibiricus Chetverikov, 1908 & $\begin{array}{l}\text { Russia, Perm, Cherdyn, } \\
\text { 6.VII.2002, K. Mikkola leg. }\end{array}$ & AM946749 \\
\hline MZH_KM13 & D. sibiricus Chetverikov, 1908 & $\begin{array}{l}\text { Russia, Perm, Cherdyn, } \\
\text { 6.VII.2002, K. Mikkola leg. }\end{array}$ & AM946750 \\
\hline MZH_KM19 & D. sibiricus Chetverikov, 1908 & $\begin{array}{l}\text { Russia, Udmurtia, Kilmez, } \\
\text { 9.VII.2002, K. Mikkola leg. }\end{array}$ & $\begin{array}{l}\text { AM946701 } \\
\text { AM946751 }\end{array}$ \\
\hline MZH_KM20 & D. sibiricus Chetverikov, 1908 & $\begin{array}{l}\text { Russia, Udmurtia, Kilmez, } \\
\text { 9.VII.2002, K. Mikkola leg. }\end{array}$ & $\begin{array}{l}\text { AM946702 } \\
\text { AM946752 }\end{array}$ \\
\hline MZH_KM21 & D. sibiricus Chetverikov, 1908 & $\begin{array}{l}\text { Russia, Udmurtia, Kilmez, } \\
\text { 9.VII.2002, K. Mikkola leg. }\end{array}$ & AM946753 \\
\hline MZH_KM23 & D. kilmez sp.n. & $\begin{array}{l}\text { Russia, Udmurtia, Kilmez, } \\
\text { 9.VII.2002, K. Mikkola leg. }\end{array}$ & $\begin{array}{l}\text { AM946705 } \\
\text { AM946728 }\end{array}$ \\
\hline MZH_KM24 & D. kilmez sp.n. & $\begin{array}{l}\text { Russia, Udmurtia, Kilmez, } \\
\text { 9.VII.2002, K. Mikkola leg. }\end{array}$ & $\begin{array}{l}\text { AM946706 } \\
\text { AM946729 }\end{array}$ \\
\hline MZH_KM25 & D. pini (Linnaeus, 1758) & $\begin{array}{l}\text { Finland, N: Tammisaari, } \\
\text { Gullö, 15.-17.VII.2002, } \\
\text { K. Mikkola leg. }\end{array}$ & AM946723 \\
\hline MZH_KM27 & D. pini (Linnaeus, 1758) & $\begin{array}{l}\text { Finland, N: Tammisaari, } \\
\text { Gullö, 15.- 17.VII.2002, } \\
\text { K. Mikkola leg. }\end{array}$ & $\begin{array}{l}\text { AM946708 } \\
\text { AM946724 }\end{array}$ \\
\hline MZH_KM28 & D. pini (Linnaeus, 1758) & $\begin{array}{l}\text { Finland, N: Tammisaari, } \\
\text { Gullö, 15.- 17.VII.2002, } \\
\text { K. Mikkola leg. }\end{array}$ & $\begin{array}{l}\text { AM946709 } \\
\text { AM946725 }\end{array}$ \\
\hline MZH_KM29 & D. pini (Linnaeus, 1758) & $\begin{array}{l}\text { Finland, N: Tammisaari, } \\
\text { Gullö, 15.- 17.VII.2002, } \\
\text { K. Mikkola leg. }\end{array}$ & $\begin{array}{l}\text { AM946710 } \\
---\end{array}$ \\
\hline MZH_KM30 & D. pini (Linnaeus, 1758) & $\begin{array}{l}\text { Finland, N: Tammisaari, } \\
\text { Gullö, 15.- 17.VII.2002, } \\
\text { K. Mikkola leg. }\end{array}$ & $\begin{array}{l}\text { AM946711 } \\
\text { AM946726 }\end{array}$ \\
\hline MZH_KM31 & D. sibiricus Chetverikov, 1908 & Russia, Burjatia, Baikal & $\begin{array}{l}\text { AM946703 } \\
\text { AM946754 }\end{array}$ \\
\hline MZH_KM32 & D. sibiricus Chetverikov, 1908 & Russia, Burjatia, Baikal & $\begin{array}{l}\text { AM946704 } \\
\text { AM946755 }\end{array}$ \\
\hline MZH_KM41 & D. kilmez sp.n. & $\begin{array}{l}\text { Russia, Udmurtia, } \\
\text { 2002, K. Mikkola leg. }\end{array}$ & $\begin{array}{l}\text { AM946693 } \\
\text { AM946730 }\end{array}$ \\
\hline
\end{tabular}


Table 1 continued.

\begin{tabular}{lll}
\hline Lab code & Taxon & Locality \\
& Date, Collector & GB acc. COI \\
& GB acc. ITS2 \\
\hline
\end{tabular}

\begin{tabular}{|c|c|c|c|}
\hline MZH_KM42 & D. pini (Linnaeus, 1758) & $\begin{array}{l}\text { Russia, Novosibirsk, } \\
\text { 1.VII.1984 }\end{array}$ & -- \\
\hline MZH_KM43 & D. pini (Linnaeus, 1758) & $\begin{array}{l}\text { Russia, Mari, } \\
\text { 12.VI.1997 }\end{array}$ & -- \\
\hline MZH_KM_J1 & D. superans (Butler, 1877) & $\begin{array}{l}\text { Japan, Honshu, Nagano, } \\
\text { Minami-Azumi, Tazawa, } \\
\text { 2.VIII.2003, M. Owada leg. }\end{array}$ & $\begin{array}{l}\text { AM946712 } \\
\text { AM946735 }\end{array}$ \\
\hline MZH_KM_J2 & D. superans (Butler, 1877) & $\begin{array}{l}\text { Japan, Honshu, Nagano, } \\
\text { Minami-Azumi, Tazawa, } \\
\text { 2.VIII.2003, M. Owada leg. }\end{array}$ & $\begin{array}{l}\text { AM946713 } \\
\text { AM946736 }\end{array}$ \\
\hline MZH_KM_J5 & D. superans (Butler, 1877) & $\begin{array}{l}\text { Japan, Honshu, Nagano, } \\
\text { Minami-Azumi, Tazawa, } \\
\text { 2.VIII.2003, M. Owada leg. }\end{array}$ & $\begin{array}{l}\text { AM946714 } \\
\text { AM946734 }\end{array}$ \\
\hline MZH_KM_J6 & D. superans (Butler, 1877) & $\begin{array}{l}\text { Japan, Honshu, Nagano, } \\
\text { Minami-Azumi, Tazawa, } \\
\text { 2.VIII.2003, M. Owada leg. }\end{array}$ & $\begin{array}{l}\text { AM946715 } \\
\text { AM946731 }\end{array}$ \\
\hline MZH_KM_J7 & D. superans (Butler, 1877) & $\begin{array}{l}\text { Japan, Honshu, Nagano, } \\
\text { Minami-Azumi, Tazawa, } \\
\text { 2.VIII.2003, M. Owada leg. }\end{array}$ & $\begin{array}{l}\text { AM946716 } \\
\text { AM946732 }\end{array}$ \\
\hline MZH_KM_J12 & D. superans (Butler, 1877) & $\begin{array}{l}\text { Japan, Idenemaizawa, Kawabe, } \\
\text { Akita Pref., } \\
\text { 1.VIII.2003, A. Sasaki leg. }\end{array}$ & $\begin{array}{l}\text { AM946717 } \\
\text { AM946737 }\end{array}$ \\
\hline MZH_KM_J13 & D. superans (Butler, 1877) & $\begin{array}{l}\text { Japan, Moriyashizawa, Moriyoshi, } \\
\text { Akita Pref., } \\
\text { 29.VII.2003, M. Tanaka leg. }\end{array}$ & $\begin{array}{l}\text { AM946718 } \\
\text { AM946738 }\end{array}$ \\
\hline MZH_KM_J14 & D. superans (Butler, 1877) & $\begin{array}{l}\text { Japan, Moriyashizawa, Moriyoshi, } \\
\text { Akita Pref., } \\
29 . \text { VII.2003, M. Tanaka leg. }\end{array}$ & $\begin{array}{l}\text { AM946719 } \\
\text { AM946739 }\end{array}$ \\
\hline MZH_KM_J15 & D. superans (Butler, 1877) & $\begin{array}{l}\text { Japan, Moriyashizawa, Moriyoshi, } \\
\text { Akita Pref., } \\
\text { 29.VII.2003, M. Tanaka leg. }\end{array}$ & $\begin{array}{l}\text { AM946720 } \\
\text { AM946740 }\end{array}$ \\
\hline MZH_KM_J27 & D. superans (Butler, 1877) & $\begin{array}{l}\text { Japan, } \\
\text { 24.VIII.2003 }\end{array}$ & $\begin{array}{l}\text { AM946721 } \\
---\end{array}$ \\
\hline \multicolumn{4}{|l|}{ Outgroups } \\
\hline MZH_KM_J19_KS1 & D. spectabilis (Butler, 1877) & $\begin{array}{l}\text { Japan, Kamikawazi, lida, } \\
\text { Nagano, 23.VIII.2003, } \\
\text { K.Shikata leg. }\end{array}$ & AM946722 \\
\hline MZH_KM_J21_KS3 & D. spectabilis (Butler, 1877) & $\begin{array}{l}\text { Japan, Kamikawazi, lida, } \\
\text { Nagano, 23.VIII.2003, } \\
\text { K.Shikata leg. }\end{array}$ & AM946743 \\
\hline MZH_KM_J24 & D. spectabilis (Butler, 1877) & $\begin{array}{l}\text { Japan, Saga Pref., Kyushu, } \\
\text { Shimotogawa, Ushizu-cho, } \\
\text { 21.VIII.2003, M. Furukawa leg. }\end{array}$ & AM946741 \\
\hline MZH_KM_J25 & D. spectabilis (Butler, 1877) & $\begin{array}{l}\text { Japan, Saga Pref., Kyushu, } \\
\text { Shimotogawa, Ushizu-cho, } \\
21 . \text { VIII.2003, M. Furukawa leg. }\end{array}$ & AM946742 \\
\hline MZH_KM38 & $\begin{array}{l}\text { L. trifolii (Denis \& } \\
\text { Schiffermüller, 1775) }\end{array}$ & $\begin{array}{l}\text { Finland, Ab: Örö, } \\
31 . \text { VII. -10.VIII.2005, light trap, } \\
\text { J. Kullberg leg. }\end{array}$ & $\begin{array}{l}\text { AM946692 } \\
---\end{array}$ \\
\hline
\end{tabular}




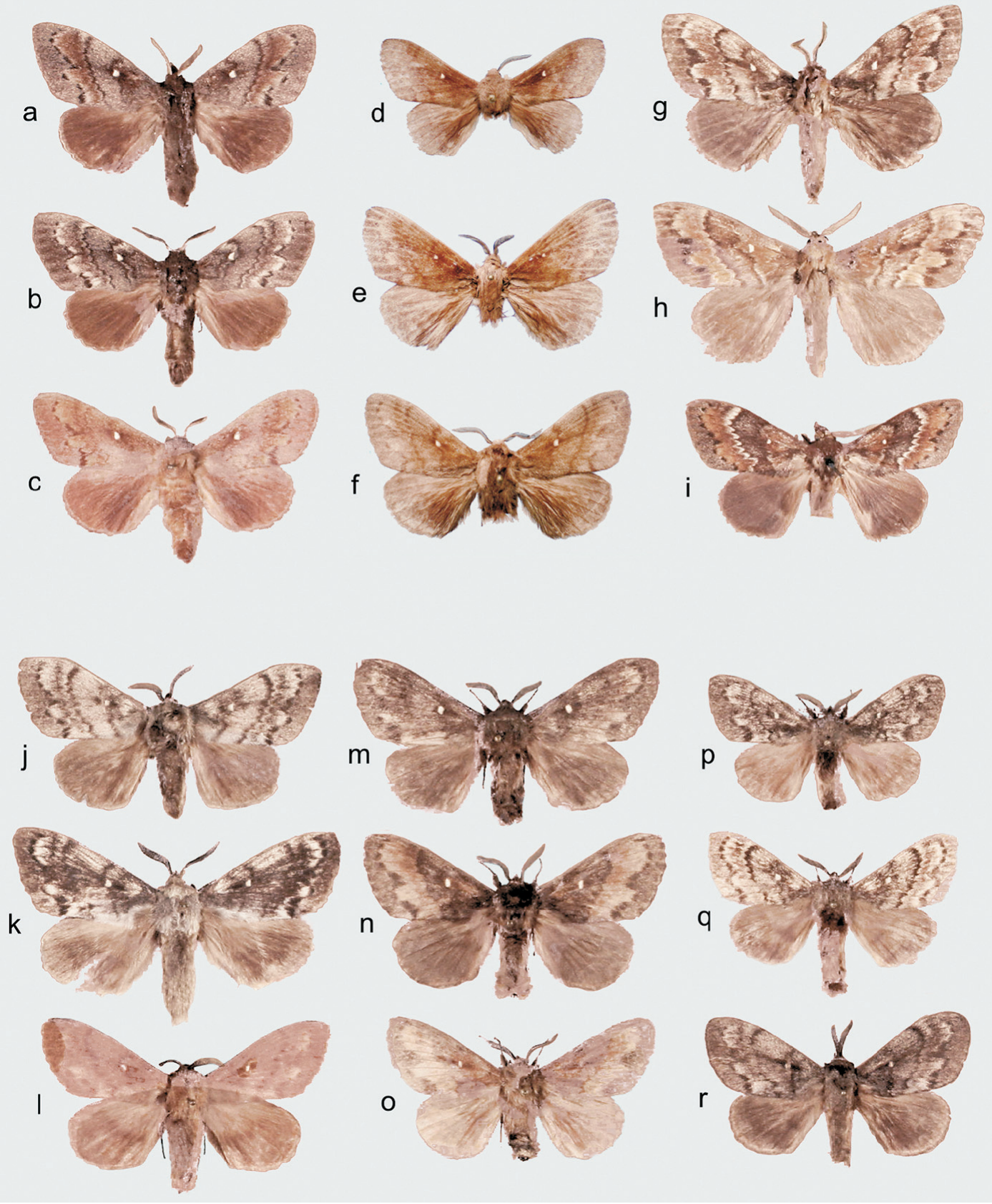

Fig. 3. Males of the species of Dendrolimus being studied, the columns also showing some intra- and interpopulation variation. - a-c. Dendrolimus pini Finland: a. Al, Mariehamn; b. Ab, Houtskär; c. N, Tammisaari. - d-f. D. kilmez sp. n. Russia: d. Udmurtia, Kilmez 10.VII.2002 (holotype); e-f. Chelyabinsk obl., Miass 28.VI.1997 (paratypes). - g-h. D. superans $2 \hat{\jmath} \widehat{\partial}$ Japan, Karuizawa. - i. D. spectabilis $1 \hat{\jmath}$ Japan, Tokyo. - j-I. D. sibiricus Asiatic Russia: j. SW Siberia, Altai; k. Central Siberia, Khamar-Daban; I. Far East Russia, Primorye. - m-o. D. sibiricus 3 ô ${ }^{\lambda}$ Russia, N Urals, Perm, $50 \mathrm{~km}$ NW Cherdyn. - p-r. D. sibiricus Russia, S Urals: p-q. $2 \hat{\partial} \widehat{\partial}$ Udmurtia, Kilmez; r.1 $\partial$ Miass. 


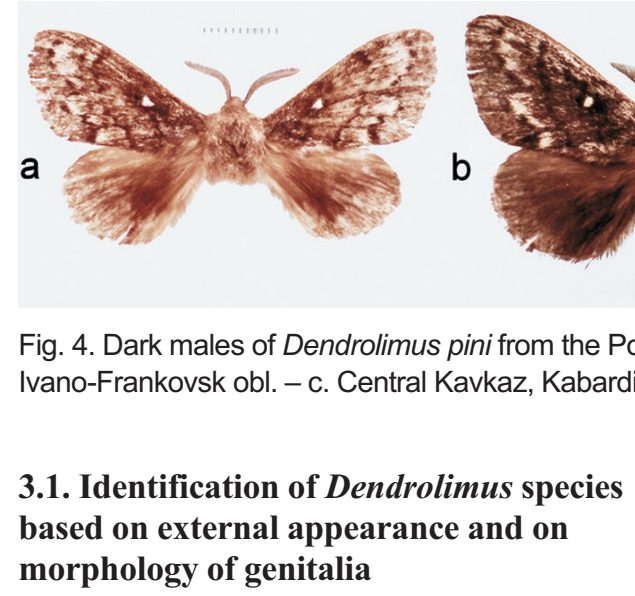

D. spectabilis is easily recognized on the basis of the disproportionately minuscule or lacking discal wing spot (Fig. 3i). D. superans may look misleadingly similar to some polymorphic forms of $D$. sibiricus, but mostly the moths of $D$. superans are larger and richer in brownish or rusty hues (Figs $3 \mathrm{~g}-\mathrm{h}$ ). D. pini, which is mostly easily recognized by its elegant contrast between the grey background and the nutbrown subterminal field (Figs. 3a-b), sometimes shows a uniformly ashgrey background colour (cf. Fig. 4), and a polymorphic rusty brown morph occurs at a low frequency (Fig. 3c). In D. kilmez sp. n., most specimens are of the latter morph (Figs 3d-f). If such a morph occurs in D. sibiricus (Fig. 31), it may be difficult to separate from D. pini and kilmez, but, actually, in D. sibiricus the brown morph occurs at a very low frequency, and predominantly in the Eastern Palaearctic (where D. pini does not occur).

The identification of species of Dendrolimus by appearance is complicated by the wide polytypism and polymorphism of most species. As mentioned, $D$. sibiricus looks different in different parts of the Ural Mts. (Figs 3m-p), and the Ural moths differ from most moths from the Altai, Khamar-Daban and Buretian Mountains (Figs $3 \mathrm{j}-\mathrm{k})$. In D. pini, single moths from the Central European Mountains as well as most moths from the Ponto-Mediterranean area are reminiscent of D. sibiricus (Fig. 4).

$D$. sibiricus could be distinguished from $D$. superans by genitalia characters, that were illustrated already by Lajonquière (1973), but which he interpreted as effects of climatic differences.
Our work was slowed down by an unexpected taxonomical observation. What in the field was believed to be a unicolorous brownish colour morph of $D$. pini, was, based on evidence from DNA sequences of the mitochondrial gene COI fragments 3' and 5', a taxon distinct from $D$. pini (Figs $3 d-f$ ). As this finding was supported by the morphology of male genitalia, which revealed a combination of small morphological characters consistently separating the taxon from $D$. pini, it is below described as a new species.

\subsection{History of Dendrolimus sibiricus in the Ural area}

The present study does not support the postulated recent spreading of $D$. sibiricus from the east, and thus, continued spreading westward. The habitus of the moths from Perm and Udmurtia differ clearly from each other, the former being mainly larger (mean \pm SD wing expanse $62.4 \pm 3.4 \mathrm{~mm}$, $\mathrm{n}=10{ }^{\lambda} \partial^{\lambda}$, Figs $3 \mathrm{~m}-\mathrm{n}$ ) and with very dark coloration, the latter mostly small $(58.6 \pm 3.4 \mathrm{~mm}$, $\mathrm{n}=17 \hat{\delta}$ :), paler and with a more restlessly irrorated appearance (Figs 3o-p). No molecular difference was detected between the populations. The following facts speak against an eastern spreading of the species:

(1) The different habitus of the populations indicates that they have lived in these areas over a long period, probably thousands of years.

(2) Notwithstanding that Eversmann (1844) did not distinguish $D$. sibiricus from $D$. pini, he revealed the presence of $D$. sibiricus in the Volgo-Ural area in two ways:

(a) Eversmann (1844) first presented a traditional description of $D$. pini, but then, under varia- 


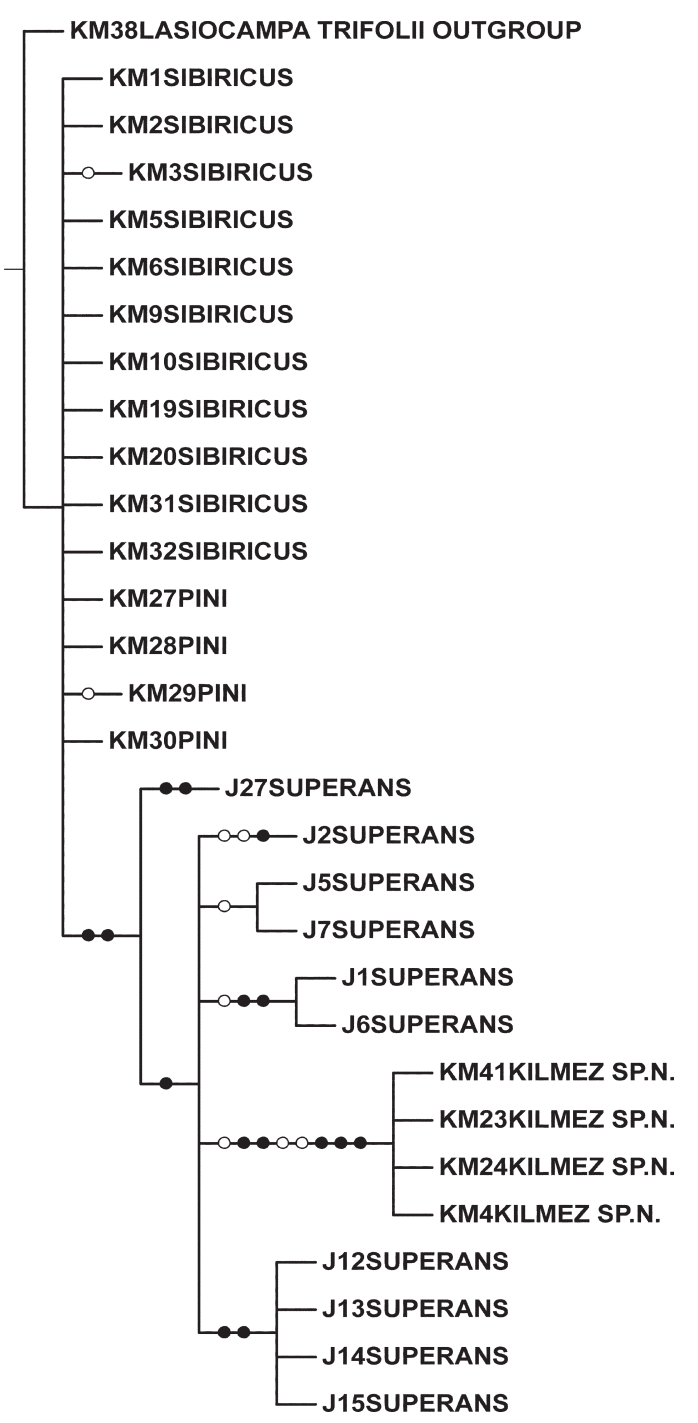

Fig. 5. COI-3', strict consensus tree of 12 equally parsimonious trees of five species of Dendrolimus (one as an outgroup), length 68 steps, $\mathrm{Cl}=0.91, \mathrm{RI}=0.92$. Each terminal represents one specimen. Open circles indicate non-unique changes, while filled circles denote unique changes. For the phylogenetic trees, see text.

tion, he said (from Latin) "all wings ferrugineous [this fits both $D$. pini and kilmez; see above] - or forewings grey, or ashy, with white spot and three dark [transverse] lines" [in the Urals this fits only D. sibiricus], and

(b) He wrote that (from Latin) "The larva that feeds on Pinus silvestris [probably from the Latin name] sometimes destroys forests; so in 1842 in the Spask [SW Urals] area." As $D$.

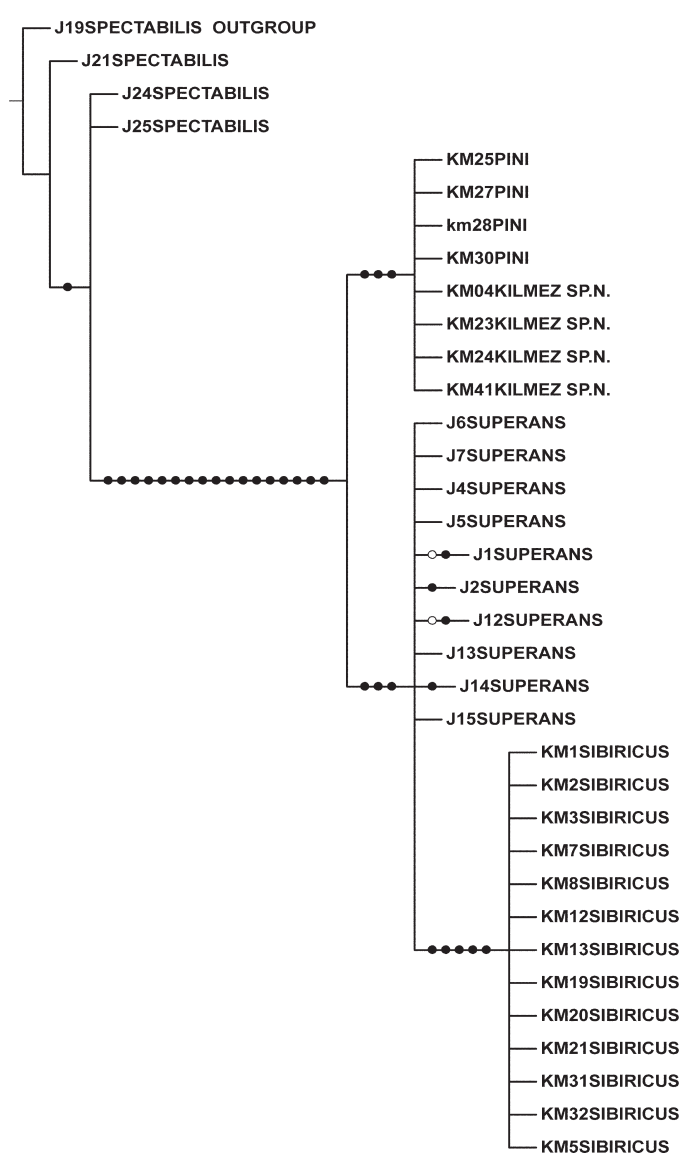

Fig. 6. ITS2, strict consensus tree of three equally parsimonious trees of four species of Dendrolimus and Lasiocampa trifolii as an outgroup, length 41 steps, $\mathrm{Cl}$ $=0.97, \mathrm{RI}=0.99$. For explanations, see Fig. 5 .

pini is rare or lacking in those areas and as it seldom "destroys forests", the pest in Spask must have been $D$. sibiricus, as it is still today.

Spreading species do usually not show differences such as those found between populations of D. sibiricus. The recently found note by Eversmann (1844) confirms that in the South Urals the species has caused forest damage for at least 60 years before the notes of Chetverikov and Petersen.

\subsection{Pheromones}

Both in Finland (only D. pini) and in Perm (only D. superans) as well as in Udmurtia (D. sibiricus 
Table 2. In the four studied Dendrolimus species, the obtained 729 bp fragment of 3'-COI region spans nucleotide positions 2231-2959, ss compared with Drosophila yakuba mitochondrial DNA sequence (Clary \& Wolstenholme 1985). Within the region, 16 non-continuous nucleotide positions were variable. Haplotypes (HT) are identified with Roman numerals.

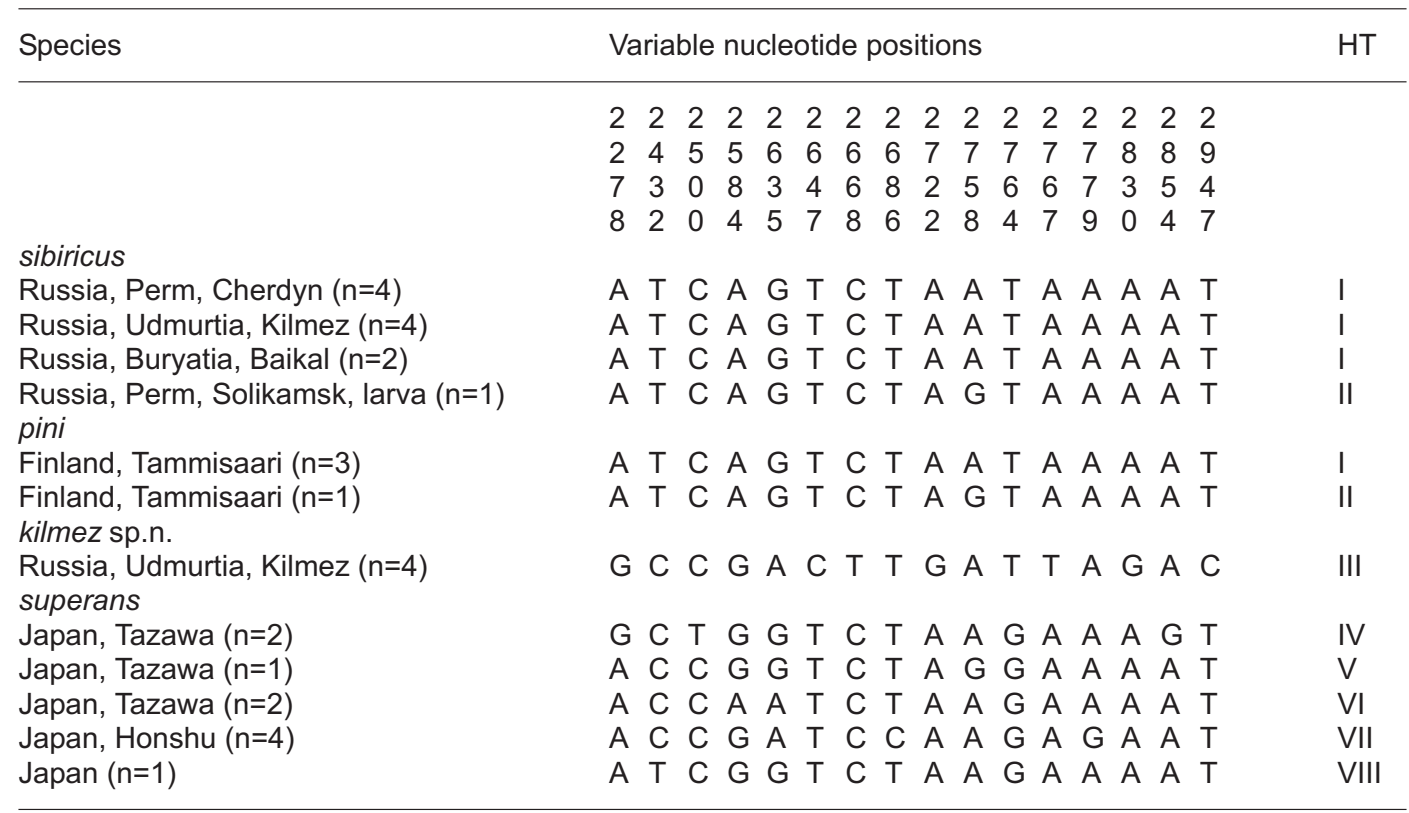

and D. kilmez sp.n.), the Dutch pheromone preparation for $D$. pini and the Russian preparation for $D$. superans collected equally well, irrespective of the species of Dendrolimus present. Thus, the preparations cannot be used for separation of the species of Dendrolimus.

\subsection{Molecular studies}

Pairwise comparisons of the COI-3' sequences between the four studied taxa showed that $16 \mathrm{nu}-$ cleotide sites $(2.19 \%)$ were variable among them, and we could define eight particular haplotypes (differing at 0-12 sites; Fig. 5, Table 2). D. sibiricus and D. pini shared two COI 3' haplotypes, D. kilmez sp.n. expressed one private haplotype and $D$. superans showed five haplotypes. D. pini and D. kilmez sp.n. differed from each other by 11 substitutions (uncorrected pairwise difference $1.51 \%$ ). Pairwise comparisons of the COI-5' sequences between the four studied taxa showed that 12 nucleotide sites $(1.98 \%)$ were variable among them, and we could define six particular haplotypes (Table 3). The COI-5' sequences were identical and distinct for $D$. kilmez sp.n. and $D$. superans, respectively.

The ITS2 sequences of $D$. kilmez sp.n and $D$. pini were identical, while $D$. sibiricus showed one private genotype and $D$. superans presented multiple genotypes (Fig. 6).

\section{Taxonomy of the Dendrolimus pini complex, the northern Palaearctic species}

The terminology and the systematic order of species follow mainly that of Lajonquière (1973) and Lemaire \& Minet (1999). For characteristics of the family Lasiocampidae, the latter work should be consulted.

\subsection{Description of the genus Dendrolimus Germar, 1812}

Type species: Dendrolimus pini (Linnaeus, 1767)

Large and bulky, hairy, brownish to greyish night-flying moths with pronounced sexual di- 
Table 3. In the four studied Dendrolimus species, the obtained $658 \mathrm{bp}$ fragment of 5'-COI region spans nucleotide positions 1614-2272, as compared with Drosophila yakuba mitochondrial DNA sequence (Clary \& Wolstenholme 1985). Wtthin the region, 12 non-continuous nucleotide positions were variable. Haplotypes (HT) are identified with Roman numerals.

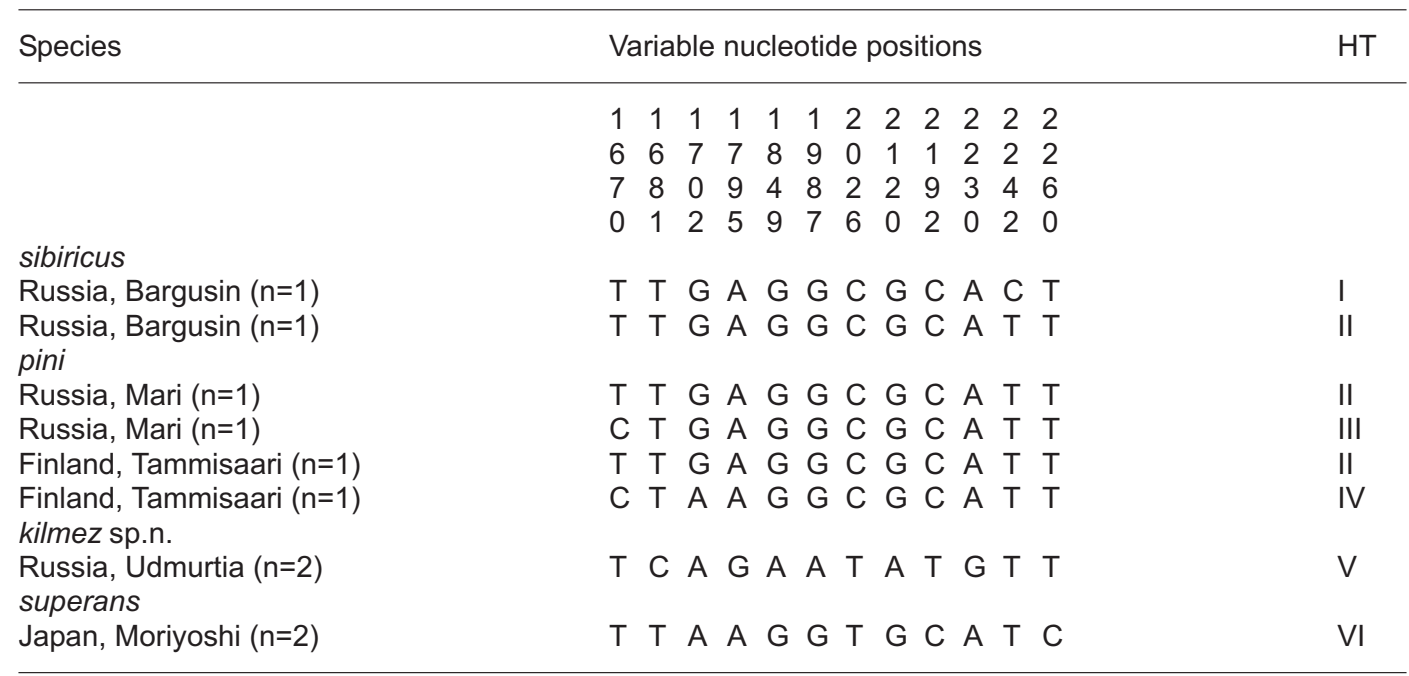

morphism. Male antenna bipectinate, female antenna with short pectination, nearly filiform. Wing expanse of males $48-70 \mathrm{~mm}$ and that of females 60-90 mm; females longer-winged and with longer body. Forewing with three transverse lines (ante- and postmedian, subterminal), and white, black-shaded central spot near or on antemedian line. Outermost line (subterminal) wavy, often outward strongly lined by blackish and/or dark rusty brown scales, space between postmedian and subterminal mostly browner than background. Often polymorphic in relation to either fully marked (usually nominate) forms or more unicolorous, rusty brownish morphs; females generally paler than males.

Male genitalia (Figs 2 and 7). Tegumen narrow transversal bar, on both sides with small pyramid-shaped socii equipped with sensory hairs. Uncus lacking or membranous flap. Valvae weakly sclerotized, finger-like hollow appendages, apically like forepart of boat. Ventrally these on both sides sac-like hairy structures, sacculi, that carry on their anal wall sclerotized vertical fold. Dorsal part of fold (that next to valva) mostly forming more or less protruding, strongly sclerotized, triangle-shaped or dagger-
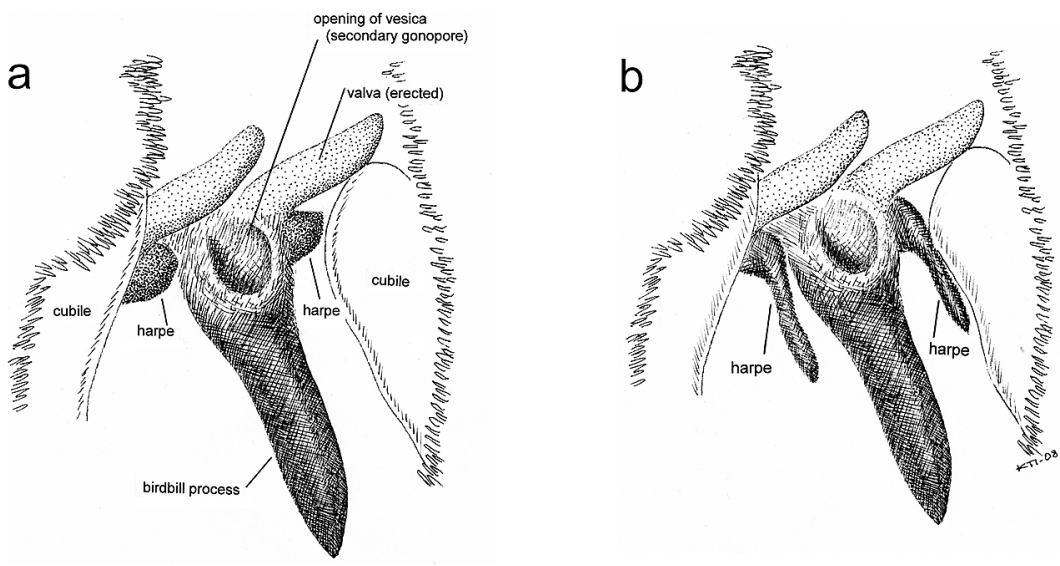

Fig. 7. Identification by brushing the male genitalia. - a. Dendrolimus pini. - b. D. sibiricus. The left cubile has been bent aside, and parts of the $8^{\text {th }}$ ventral sclerite, as well as a large amount of scales, have been removed. In D. pini, three appendages become visible, while there are five such appendages in $D$. sibiricus. 


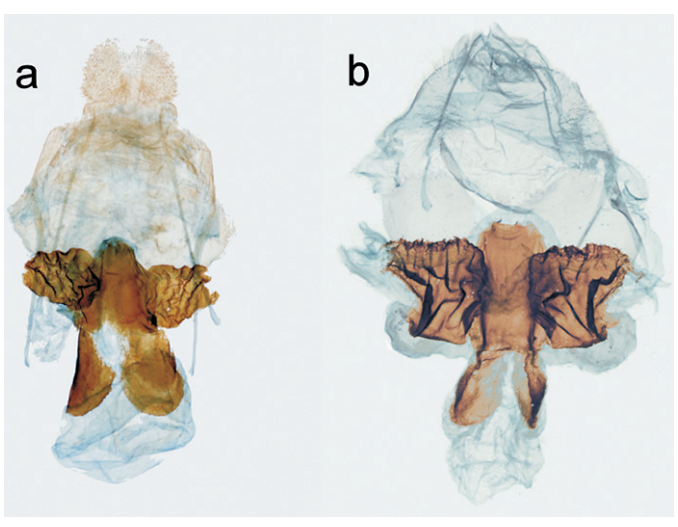

Fig. 8. The female genitalia of two species of Dendrolimus. - a. D. pini, Finland, Tvärminne. - b. D. sibiricus, Russia, Primorye.

like process, parallel with valva, called here harpe (main variable specific character in genus, cf. Figs $32-42$ by Lajonquière 1973). Ventrolaterally to sacculi on both sides large but mainly non-sclerotized ventrolateral concave flaps ( $\mathrm{cu}$ biles sensu Lajonquière), originating from vinculum. Cubiles apically with small but strongly sclerotized, shoe-like extensions (talons of Lajonquière), armed with numerous spines. Order and number of spines show intra- and interspecific variation that seems taxonomically nonsignificant.

Of male internal genitalia, aedeagus reduced to weakly sclerotized ring, not much longer than wide, but with large apical, ventrocaudally directed, strongly sclerotized, laterally flattened and dorsally toothed birdbill-like process. Vesica in everted condition tower-like vertical structure on top of aedeagus (Fig. 2a), with two lateral, more or less arm-like, often asymmetric diverti- cula that carry variable amounts of apical cornuti of variable size. Everted ductus ejaculatorius arising anteriorly of central line between diverticula of vesica, at least basally directed cephalad.

Female genitalia (Fig. 8). Anal papillae weak and cushion-like, two pairs of long and thin apophyses. Wide ostium bursae surrounded by large lamina antevaginalis, divided laterally into large sclerotized folded flaps ("coussinets subvaginaux" of Lajonquière). Between them, ventrally strongly sclerotized ductus bursae ("sac vaginal"). Apically, inside corpus bursae, ductus carrying two lateral sclerotized concave plates, spiny on median surface ("épaulements"). Corpus bursae proper small, membranous, without signum.

Functional aspects as inferred from genitalia structures. The genitalia are highly apomorphic, and their homologies with the basic lepidopteran morphology are not easily recognized. The male vincular extensions, the cubiles with talons, that in resting position protect other genitalia, have seemingly taken over the role of valvae of many other lepidopteran groups in the primary holding of the female abdomen in a position making the intromission of male genitalia possible. The valvae may be more sensory while the harpe seemingly interplays with the coussinet of the lamina antevaginalis (deeper in D. sibiricus with longer harpe, Figs 2 and 8). The male birdbill process probably presses the ductus bursae (its ventral trough-like sclerotization) ventrad, by doing so opening the way along the ductus for the towerlike vesica. The arms of the vesica with apical cornuti then press the épaulements laterally to keep the ductus open. If this is correct, the apparently opposite (frontal) direction of the distal part of ductus ejaculatorius, in copulation posture,
Fig. 9. Two Matsumura syntypes designated here as lectotypes:

- a. Dendrolimus albolineatus ( $=D$. sibiricus). - b. D. jezoensis (=D. superans). National Science Museum, Tokyo.

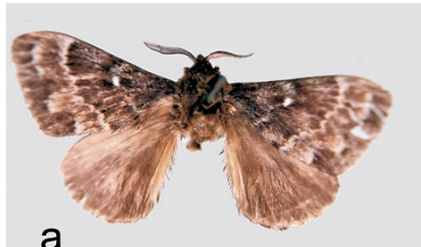

a

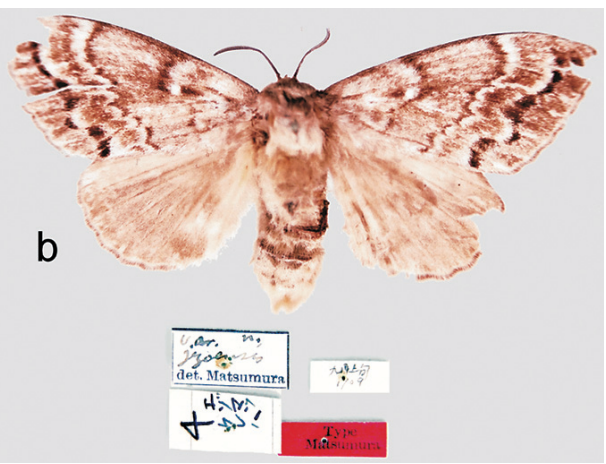


looks odd (it may be an artefact caused by the extension of the cut structure).

Identification by brushing. The cubiles of the median part of vinculum were interpreted by Lajonquière as derivations of intersegmental membranes 8-9. In vivo and in collection specimens (Fig. 7), the cubiles are in a palm-like manner bent medially such that the talons leave only a narrow view to the median parts of genitalia. The two taxa, $D$. pini and $D$. sibiricus, can be differentiated by cleaning the male external genitalia, particularly by removing the thick abdominal scales and the caudal parts of the 8th ventral sclerite and by bending aside or removing one of the cubiles. In the former species, the harpe is short and flat, triangular, practically invisible under the valve, in the latter dagger-like, extending out at least half of the length of valva. In this respect, $D$. sibiricus does not differ from $D$. superans, but the harpe of the latter is basally stouter. Thus, in D. sibiricus and $D$. superans, there are, in addition to the median birdbill-like process, four caudal appendages, while only two such ones are present in $D$. pini and D. kilmez.

\subsection{Species number and distribution}

Lajonquière (1973) listed 12 species of Dendrolimus, of which 9 are found exclusively in China except one that has also been found in Sikkim. Five of the Chinese species were described as new by Lajonquière from the well-known Höne material in Museum Alexander Koenig in Bonn. In this revision, the five species that occur in the northern Palaearctic and outside China are treated. Because one species is split into two here and one is described as new, and as Zhang et al. (2004) add D. houi Zhang, Kon \& Liu from China, the number of species in the genus Dendrolimus is now, as far as we know, 15.

Because this work is mainly based on DNA sequences and evertions of vesicas, and because the type materials have been examined by Lajonquière (1973), the types were not examined again here. It was taken for granted that specimens from Finland represent $D$. pini, those from Central Siberia $D$. sibiricus and materials from Japan D. superans and D. spectabilis. The latter ones are easily separated from each other by ap- pearance. All show specific characters in the male genitalia. We have not attempted to treat the numerous names given with subspecific or infrasubspecific status, or synonyms of species, as this was not within the scope of our paper (except two Matsumura names; cf. Lajonquière 1973).

\subsection{Keys to the males of Palaearctic species of Dendrolimus occurring outside China}

\subsubsection{Habitus, based on forewing pattern (without taking into account colour forms, which are often impossible to determine without association to local specimens or without aid of genitalia):}

1. Discal dot very small or non-existing (but cf. D. kilmez sp.n.), subterminal line mostly strongly maculated at vein spaces, serration of postmedian line often contrastingly visible against white background spectabilis

- Discal dot sharp, black-lined and white-centred, subterminal line unclearly interrupted at veins, postmedian line smoother 2

2. Medium-sized or small, subterminal line outward with narrow, blackish or brownish shade

- Medium-sized to very large, subterminal line with deep shades between waves 4

3. Medium-sized, forewing ground colour mostly finely ash-grey, subterminal field contrastingly nut-brown, sometimes more evenly grey or brownish with transverse lines less contrasting pini

- Small Dendrolimus, usually evenly rusty brownish with weak transverse lines, costal spot small, grey-and-brown morph probably with softer markings than in D. pini

kilmez sp. n.

4. Ground colour mostly dark grey, unevenly irrorate, and with paler patches, or more uniformly blackish, subterminal field only weakly brownish (except in infrequent forms)

sibiricus

- Ground colour mostly grey-brown to rusty brown, subterminal field then distinctly reddish nut-brown, often with unicolorous brown groundcolour superans 


\subsubsection{Key to male genitalia}

1. Anal fold of sacculus dorsally with sclerotized process, harpe; vesica with lateral diverticula

\section{2}

- Harpe of sacculus lacking; vesica without pronounced diverticula

spectabilis

2. Harpe less than third of length of valva; cornuti of vesica of medium size

- Harpe around half or more of length of valva, dagger-like; cornuti of vesica either small or large

3. Harpe triangular, slightly higher than wide; vesica triangular pini

- Harpe shallow knot or, if triangular, lower than wide; vesica with arm-like diverticula

kilmez sp.n.

4. Harpe for most part with parallel margins, dagger-like; cornuti of vesica sibiricus

- Harpe basally wide, gradually tapering; cornuti of vesica large

superans

\subsection{Dendrolimus pini (Linnaeus).}

Figs 3a-c, genitalia Figs 2a, 8a and 7a.

Phalaena (Bombyx) pini Linnaeus, 1758; Syst.Nat. X edit.1: 498.

Type locality: Not given [Europe, probably Sweden].

Note: Lajonquière (1973) gives the date as 1767 (referring to Syst. Nat. XII).

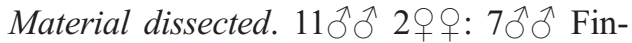
land, N: Tammisaari, Gullö 5956'N 2323'E;

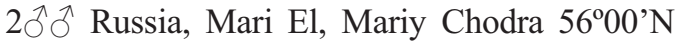

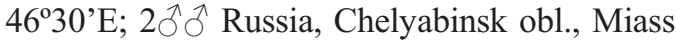

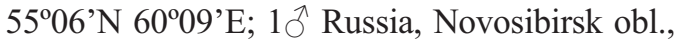
Akademgorodok $55^{\circ} 10^{\prime} \mathrm{N} 83^{\circ} 00^{\prime} \mathrm{E}$; $1 \delta^{\Uparrow}$ Greece, Arkadia ca. $37^{\circ} 30^{\prime} E 22^{\circ} 30^{\prime}$ E. 2 우: Finland, V: Dragsfjärd, Örö and U: Tvärminne. In addition, a number of males were brushed, e.g. from Greece and from the Tatra Mts. (Poland) and the Caucasus.

Size and colouration. Medium-sized Dendrolimus, wing expanse in Finnish material (Marttila

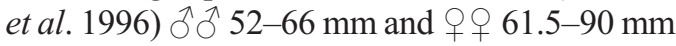
(averages 58.8 and 74.6, respectively). Specimens from Mari El and Chelyabinsk Area seem smaller than in Finland: 4 रे $\sigma^{\lambda}: 51-58 \mathrm{~mm}$. de Freina \& Witt (1987) give the wingspans as 50-
70 and $55-80 \mathrm{~mm}$. Nominate morph (Figs 3a-b) characterized by fine and smooth markings and elegant coloration of forewing, background colour ash-grey, belts inward from antemedian and between postmedian and subterminal lines contrastingly chestnut-brown, sometimes more evenly greyish. In brown morph (Fig. 3c; f. unicolor-brunnea, frequency low in Finland but dominating in Mari El), background colour changed to rusty brown, transverse lines usually weakened. Submarginal line dark brown, its posterior bulge roundish, at costa antemedian line, if visible, mostly arching medially (cf. $D$. sibiricus). From Caucasus to Greece (and elsewhere in the Mediterranean area, the species is mostly uniformly greyish and roughly marked, and often misleadingly similar to D. sibiricus (Fig. 3; cf. Rougeot \& Viette 1980: P1. 29: i).

Male genitalia (Fig. 2a): Tip of valva roundish. Anal fold of sacculus sometimes wavy. Harpe of sacculus short, triangular, mostly slightly longer than wide, in caudal view visible as shallow blackish plate only. Everted vesica, in dorsal view, usually triangular with transversal anal wall, its apical cornuti of medium size (in one specimen lateral extensions more arm-like, but anal wall straight).

Female genitalia (Fig. 8a): The lateral plates of lamina antevaginalis are smaller and less deeply folded than in D. sibiricus.

Distribution. Most of Europe, also NW North Africa and Asia Minor (Bithynia; Hatay) to the Caucasus and Near East, and is missing only from the subarctic and high-mountaineous parts, and from the British Isles (found as casual guest), Sicily and southern Italy as well as from Krim. The easternmost specimens in the present material are from Mari El between Moscow and the Ural Mts, from Miass, Chelyabinsk Area on the eastern slope of the Urals, and from Novosibirsk, Western Siberia. Lajonquière (1973) surprisingly mentions Verkhne-Udinsk, Trans-Baikalia, and states the genitalia to be identical with his specimen from Thüringen, Germany (labelling error?).

Note: Rougeot \& Viette (1980) mention six subspecies from the Mediterranean area and de Freina \& Witt (1987) five.

DNA sequences. ITS2 sequences identical to those of $D$. kilmez sp.n., COI-3' sequences pres- 
ent two haplotypes, both of which are shared with D. sibiricus.

\subsection{Dendrolimus kilmez sp.n.}

Fig. 3d-f, genitalia Fig. 2b.

Material examined and dissected. Holotype: ${ }^{\lambda}$, Russia, Udmurtia, Kilmez $57^{\circ} 00$ 'N $51^{\circ} 05^{\prime} \mathrm{E}$, 10.VII.2002 K. Mikkola leg. (MZH). Paratypes:

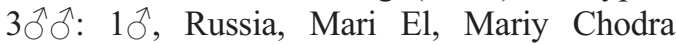
560ㅇN 46³0'E, 13.VI.1997 K. Mikkola leg.; $2{ }^{\Uparrow}{ }^{\Uparrow}$ Russia, Chelyabinsk obl., Miass $55^{\circ} 06^{\prime} \mathrm{N}$ 6009'E 28.VI.1997 K. Nupponen leg. (MZH and Coll. Nupponen). In addition, the genitalia and/or DNA sequences of the following specimens were studied: $3 \hat{\jmath} \widehat{0}$ from Kilmez and $1 \hat{\sigma}$ from Mari El, both K. Mikkola leg. (microscopic slides in MZH, sequences in GenBank).

Type locality. The village and river of Kilmez (Кипъмезъ) in Udmurtia, Russia.

Description. Clearly smaller than $D$. pini in Finland: $4{ }^{\uparrow} \sigma^{\lambda}: 48,56,56$ and $56 \mathrm{~mm}$, but does not deviate in size from $D$. pini from the Southern Urals (see D. pini). Male antenna as in $D$. pini, with long double pectinations, equipped with double rows of cilia. Labial palpi pale brown, length of proboscis less than diameter of eye. Forewing of relatively tapered shape, uniformly brown. Space between postmedian and antemedian lines slightly paler and more grey, wavy subterminal line medially with paler shade, subterminal fascia slightly more reddish than background. Transverse lines weak, more rusty brown than background. White discal spot small, situated on antemedian line. Hindwing evenly brown, but apically slightly paler.

Note: The brown morph is probably indistinguishable by appearance from the morph of $D$. pini. One male, probably of $D$. kilmez sp.n., corresponding to the nominate form of $D$. pini, was seen in Kilmez among the glue-trapped material. All specimens available (four type specimens and four glue-trapped specimens dissected and/or sequenced) represent the brown form.

Male genitalia (Fig. 2b). As in D. pini, but anal fold of sacculus mostly wavy and its harpe lower, if triangular, wider than high. Lateral diverticula of everted vesica arm-like, directed at small angle laterocaudad, causing anal wall of vesica (in dorsal view) to be shallowly V-shaped. Apical cornuti of medium size.

Female. Unknown.

Larva. Unknown.

DNA sequences. The nuclear ITS2 identical to that in $D$. pini, but the mitochondrial COI-3' sequences differ by 11 substitutions from those of D. pini (uncorrected pairwise divergence $1.51 \%$ ) and the COI-5' sequences differ by 9-11 substitutions $(1.37-1.67 \%)$ (specimens collected at Kilmez).

Etymology. From the type locality; the name is a noun in apposition.

Note: The name can be pronounced "kilmes".

\subsection{Dendrolimus spectabilis (Butler)}

Fig. 3i, genitalia Fig. 2e.

Odonestis spectabilis Butler, 1877; Ann. Mag. Nat. Hist. Ser. 4, 20: 481.

Type locality: [Yokohama] Japan.

Note: The lectotype of this taxon is an extremely melanic female (Lajonquière 1973: 533).

Oeona segregatus Butler, 1877; ibidem, p. 482.

Type locality: [Yokohama] Japan.

Note: This is the more common form of the species. Lajonquière (1973: 537) reports the taxon, in addition to Japan, from China, Mandchuria and Korea.

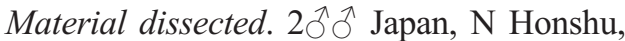
Akita pref. $39^{\circ} 30^{\prime} \mathrm{N} 140^{\circ} 30^{\prime} \mathrm{E}$ and Nagano pref. $36^{\circ} 20^{\prime} \mathrm{N} 138^{\circ} \mathrm{E} .7{ }^{\wedge} \mathrm{O}^{\circ}$ from Akita and Nagano prefectures and $5 \hat{\jmath} \hat{\jmath}$ from Kyushu, Saga pref. $33^{\circ} 13^{\prime} \mathrm{N} 130^{\circ} 10^{\prime} \mathrm{E}$ were DNA sequenced.

Size and colouration. Medium-sized to large species of Dendrolimus. Extremely polymorphic, entirely brown-grey with warm brown subterminal field or entirely brown. Best recognized from the two following species by small, point-like discal spot (sometimes missing).

Male genitalia (Fig. 2e). All processes shorter or smaller than in the next two species.Valva short, sacculus without harpe. Birdbill-like process of aedeagus small; diverticula of everted vesica short or non-existent, cornuti of medium size.

Female genitalia. Not studied.

Distribution. The most common species of Dendrolimus in Japan, also inhabiting the eastern parts of China and Korea. 


\subsection{Dendrolimus sibiricus}

\section{Chetverikov stat. rev.}

Figs 3j-q, genitalia Figs 2c, $8 \mathrm{~b}$ and $7 \mathrm{~b}$.

Dendrolimus laricis Chetverikov, 1903; Soc. Entomol. 18: 89. Unused senior synonym (cf. ICZN 23.9.1.).

Dendrolimus sibiricus Chetverikov, 1908, stat. rev.; Rev. Ent. Russ. 8: 1.

Type locality (as in D. laricis): Ural, Sayan and Bureya [Buretian] Mts. [Russia].

Note: Chetverikov (1908: 1) gave a nomen novum $D$. sibiricus to his own $D$. laricis Chetverikov, 1903 because N. J. Kusnetsov had informed him that Hübner (1790, II (2): 48) had already described a taxon of Dendrolimus with the name laricis. However, the illustration of Phalaena Bombyx laricis Hübner is certainly not a Dendrolimus (possibly Taragama sp.; less pectinated antennae than in Dendrolimus, and longer abdomen, different transversal lines and discal spot). Petersen (1905) considered $D$. laricis Chetverikov a synonym of $D$. segregatus (Butler), possibly because from the Romanov collection in St. Petersburg he had been sent wrongly determined voucher material from the Far East (seemingly $D$. sibiricus under the name $D$. segregatus).

Dendrolimus albolineatus Matsumura, 1921, stat. rev.; Thous. Ins. Jap. Addit. 4: 918.

Type locality: Island of Sakhalin (Japan/Russia).

1今 labelled "Dendrolimus albolineata [sic] Mats.; Saghalin, Adachi, Isshiki, 25.VII.1919 [verso]; Type Matsumura [red]", without abdomen, studied from colour print (National Science Museum, Tokyo; Fig. 9a), here designated lectotype.

Material dissected. $6 \hat{\jmath}: 4 \hat{\partial}$ Russia, Perm obl., 50 km NW Cherdyn $60^{\circ} 30^{\prime} \mathrm{N} 56^{\circ} 20^{\prime} \mathrm{E}$; $1{ }^{\lambda}$ Russia, Udmurtia, Kilmez $57^{\circ} 00^{\prime} 51^{\circ} 05^{\prime} \mathrm{E} ; 10^{\lambda}$ Russia, Chelyabinsk obl., Miass $55^{\circ} 06^{\prime} \mathrm{N} 60^{\circ}$ 09'E. The following specimens were used for

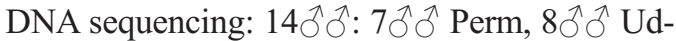
murtia, and 1 caterpillar from Perm, Solikamsk $59^{\circ} 40^{\prime} \mathrm{N} 56^{\circ} 50^{\prime} \mathrm{E}$. Numerous males from Siberia were brushed.

Size and colouration. Large species of Dendrolimus, in a museum material (MZH) of 98 specimens extreme wingspan measurements of males $51-70 \mathrm{~mm}$, most specimens between 58 and $68 \mathrm{~mm}$. Relatively broad-winged. In its main Siberian form, mostly uniformly grey, roughly scaled and unevenly speckled, subterminal line with wide terminal shade (particularly at anal margin) and blackish subterminal area ornamented by paler flecks, but with little if any brown hue. Posterior bulge of subterminal line usually rectangular, and antemedian line ends, if visible, at costa at right angles (cf. $D$. pini). The form corresponding to the nominate form of $D$. pini is much darker, even blackish, and the nutbrown colour is weakly visible. Note: Of the mentioned museum sample of 98 specimens (MZH), 77 (78.6\%) are of the main grey form, 7 (7.1\%) have a nut-brown subterminal area (but are much darker than $D$. pini), $9(9.2 \%)$ are melanic and $5(5.1 \%)$ are of a unicolourous rusty brown morph. All the unicolourous brown ones (Fig. 31, lowest moth), determined from the harpe, are from Eastern Siberia or the Russian Far East. Most of the pini-like but darker moths are from Perm. The melanics are mainly from Buryatiya, two of them from the Altai Mts. Most of Udmurtian moths are small, grey and variegated in appearance.

Male genitalia (Figs 2c, 7b). Harpe like a thin dagger, lateral extensions of vesica arm-like, laterally equipped with relatively weak cornuti.

Female genitalia (Fig. 8b). The lateral coussinets of lamina antevaginalis wide and deeply folded.

$D N A$ sequences. ITS2 sequences presented a particular haplotype, COI-3' sequences $(n=11)$ showed two haplotypes, both shared with $D$. pini. DNA sequences from a caterpillar from Perm did not differ from those generated from adults.

\subsection{Dendrolimus superans (Butler)}

Odonestis superans Butler, 1877, Ann. Mag. Nat. Hist. 20: 481.

Type locality: [Yokohama] Japan.

Dendrolimus jezoensis Matsumura, 1921, stat. rev.; Applied Ent. Japan p. 687.

1 pale + labeled "n. var. jezoensis det. Matsumura; Sapporo, Matsumra [sic]; [Japanese] 1909 [verso]; [Japanese]; Type Matsumura [red]", in good condition, but pieces missing on forewing tips and on right hindwing, studied from 
colour print (National Science Museum, Tokyo; Fig. 9b), here designated lectotype.

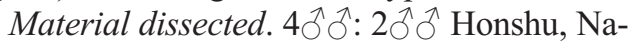

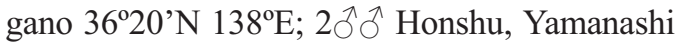
$35^{\circ} 55^{\prime} \mathrm{N} 138^{\circ} 25^{\prime} \mathrm{E}$. The following males were

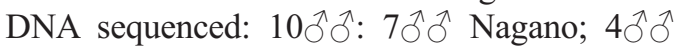
Akita pref. 39³0'N 140³0'E.

Size and colouration. Large Japanese Dendrolimus species. Very polymorphic. Forewing markings, if visible, similar to those of $D$. sibiricus, but background colour mostly rusty brownish, if greyish, with brownish hue. Antemedian line mostly turning inward at costa, but does not end medially of discal dot. Hind bulge of subterminal line of more irregular shape.

Male genitalia (Fig. 2d). Harpe long, daggerlike, basally wide and tapering in apical direction. Lateral extensions of vesica with very strong cornuti.

Female genitalia. Not studied.

DNA sequences. Both gene fragments showed higher intraspecific variability (4 genotypes for ITS2, and five haplotypes for COI-3') than in other taxa of this study.

\section{Discussion}

In the Palaearctic genus Dendrolimus, now with 15 species, the genitalia are structurally extremely uniform. This is highly evident from the numerous and accurate drawings by Lajonquière (1973). He explained some differences as the result of the action of climatological factors, thus not of taxonomic importance. In his Figs. 15/16 and $17 / 18$, he very precisely shows some of the main differences between $D$. sibiricus and superans. However, he doubted that these "quantitative" [his quotes] differences could permit a qualified separation of species (Lajonquière 1973: 544).

At present, taxonomical resolution has two more technical aids: the eversion technique of genitalia and molecular taxonomy. By using these techniques, we can conclude that Lajonquière's drawings present valid and consistent species-specific characters. However, the recent use of artificial female pheromones does not result in species distinctions.

The difficulty of determining species of
Dendrolimus based on appearance is verified in that Eversmann (1844), an exceptionally sharpeyed lepidopterist, determined the two to three species of his Volgo-Uralian area as one, D. pini. The commonly wide polymorphism and individual variation in populations result in species distributions having an important role in identification of the species based on appearance. Keys such as ours work well only for the nominate forms of species. For unambiguous species recognition, studies of genitalia and DNA sequences are required.

The colour variation of populations and species of Dendrolimus is probably related to the trunk colouration of their host trees. Thus, the trunks of Larix sibirica and Abies sibirica are dark grey, as is D. sibiricus in Siberia. In Northern Europe, $D$. pini is equipped mostly with reddish markings that match the trunks of Pinus silvestris. In the Ponto-Mediterranean area, the moths of the same species are dark grey, as are the trunks of Pinus halepensis and other pines (cf. Figs 3a-c and 4). Identification based on male genitalia, through microsopic slides or by brushing the specimens, is often necessary with such specimens.

DNA sequences can be used to augment taxonomy and species delimitation either as corroborating evidence for testing hypothesis or as starting points for further testing by other means (DeSalle et al. 2005, Vogler \& Monaghan 2007). However, by using only a single locus, information may be deceptive and insufficient to characterize species, thus producing spurious results. An integrated approach that uses mtDNA (here $\mathrm{COI}$ ) and nuclear DNA (here ITS2) in conjunction with morphology, zoogeography and ecology has the potential to produce better elucidated and supported hypotheses, which are essential for assessing and understanding biodiversity.

In our study, D. sibiricus shared COI haplotypes with $D$. pini, while $D$. kilmez shared ITS2 genotypes with $D$. pini. All D. superans haplotypes and genotypes were distinct and unrelated to the other ingroup taxa. The heterogeneity of $D$. superans between specimens from different Japanese populations is interesting, but not within the scope of the present study.

Shared COI haplotypes between closely related taxa have been repeatedly observed in sev- 
eral recent studies on insect molecular systematics (e.g. Smith et al. 2007, Milankov et al. 2008). This phenomenon is explained as incomplete lineage sorting after recent speciation or as mitochondrial introgression. Infection by maternally transmitted endosymbionts, such as Wohlbachia, is known to cause mitochondrial genes to flow between biological species, meaning that the mtDNA from one taxon completely replaces that in another, without any evidence of nuclear introgression or morphological signal (Ballard \& Whitlock 2004, Hurst \& Jiggins 2005). These results also suggest that COI sequences $\left(5^{\prime}\right.$ or $3^{\prime}$ fragments) should not be used as a single marker for species delimitation. Problems with delimitation of closely related species using exclusively COI barcodes have been shown repeatedly (e.g. Kaila \& Ståhls 2006, Rubinoff 2006). A common consensus is that evidence from different sources, such as morphological and zoogeographical data and molecular evidence from more than one molecular locus, should be used for species delimitation and identification (e.g. Dayrat 2005, Roe \& Sperling 2007).

Comparison of the obtained COI-3' haplotypes produced by us with a smaller data set of COI-5' haplotypes from the BOL lab revealed similar patterns. The congruence of the phylogenetic signals from COI-5' and COI-3' fragments was largely supported by the ITS2 data and consistently supported by morphology.

The view about the eastern origin of $D$. sibiricus that arose among early $20^{\text {th }}$ century scientists has been maintained by Russian researchers today, although the prediction about the continued spreading westward has been weakly documented. The new data about a difference in habitus of the Uralian populations and the recently found report on the species in the Urals in the first half of the $19^{\text {th }}$ century show that $D$. sibiricus is an old species in the area. The possibility of importation with timber was not investigated in this study.

There are three additional reasons to doubt that the populations would move westward: (1) Wide lack of the preferred host plants (Larix, Pinus cembra sibirica and A. sibirica), as well as (2) an increasingly Atlantic-type climate and (3) possible competition from the local species, namely $D$. pini (e.g. through parasitoids).
The taxonomic distinctness of $D$. kilmez $\mathrm{sp} \mathrm{n}$. from $D$. pini was detected from a series of COI substitutions. Small differences of male genitalia supported the specific difference. As mitochondrial COI generally evolves faster than nuclear ITS2, it seems apparent that the new species is an evolutionary young lineage. This is also evident from its restricted area of occurrence in the southern half of the Ural area. Its integrity is shown by $D$. pini occurring sympatrically with it on both sides of the mountain range.

How can we zoogeographically explain the occurrence of an endemic species in the southern Ural Mts.? Most probably during the Pleistocene glaciations and the following periods of dry climate, the Ural population of the ancestor of $D$. pini and D. kilmez sp. n. remained isolated and drifted genetically away from the mother population. Why then is $D$. pini also occurring at least in western Siberia, "behind" D. kilmez? Possibly $D$. pini has not been living in Siberia for long, instead spreading there relatively recently, when climatic conditions have been favourable for coniferous forests. An alternative explanation is that $D$. kilmez is specialized on L. sibirica and/or $A$. sibirica, which grow in the southern Ural Mts. These genera are not mentioned as host plants of D. pini in a European handbook on forest pests (Wellenstein 1978).

Acknowledgements. We are indebted to the Director of the Finnish Plant Protection Department (KTTK), Hannu Kukkonen, for supporting the expedition to Perm and Udmurtia, Russia, and to the Russian quarantine authorities in Perm and Udmurtia, A N. Omysheva and R.V. Kotelnikov, respectively, with their helpful personnel, for pleasant assistance in arranging the collecting excursions, and to B I. Kovalev for a larval sample of D. sibiricus, and to M. Kozlov and an anonymous reviewer for thorough reviewing of the manuscript. We are also grateful to Dr. S.P. Chesnokova who was kind enough to organize the field trip and act as an interpreter, to O. Hukka (KTTK) for acting as a field assistant and interpreter. We are grateful to all persons who contributed to the study by providing Dendrolimus specimens: Japan: M. Owada, M. Furukawa, M. Kimura, Y. Kishida, M. Okura, A. Sasaki, K. Shikata and M. Tanaka; S Ural Mts.: K. Nupponen and M. Ahola; the Russian Far East: V.S. Kononenko; Dr. Owada also sent photographs of two Matsumura types. Drs. P. Hebert (Guelph, Canada) and J.D. Lafontaine (Ottawa, Canada) provided comparative mtDNA sequencing, which is gratefully acknowledged. We are further grateful to the following institutions and persons: to Suomen Kulttuurirahasto for funding the DNA sequencing, to the Finnish Plant Pro- 
tection Department for funding the colour illustrations, to K. Nissinen, Z. Kolev and R. Talman for photographic assistance and to E. Rättel for assistance in DNA sequencing work.

\section{References}

Anonymous 2001: Dendrolimus superans (Butler). Siberian Silk Moth. Canadian Food Inspection Agency. Plant Pest Information. [www document] URL www.aphis.usda.gov/plant_health/plant_pest_info/ pest_detection/downloads/pra/dsuperanspra.pdf. (Accessed 21 April 2008)

Ballard, J. W. O. \& Whitlock, M. C. 2004: The incomplete natural history of mitochondria. - Molecular Ecology 13: 729-744.

Beebe, N. W. \& Saul, A. 1995: Discrimination of all members of the Anopheles punctulatus complex by polymerase chain reaction-restriction fragment length polymorphism analysis. - American Journal of Tropical Medicine and Hygiene 53: 478-481.

Butler, A. G. 1877: Descriptions of new species of Heterocera from Japan. Part I. Sphinges and Bombyces. Annals and Magazine of Natural History 20: 473-483.

Chetverikov, S. S. 1903: Dendrolimus laricis Tschwr. nov. sp. - Societas Entomologica 8: 89-90.

Chetverikov, S. S. 1908: Noch einmal über Dendrolimus pini L., D. segregatus Butl. und D. sibiricus Tshtvr., nom. nov. (laricis Tshtvr.). (Lepidoptera, Lasiocampidae). - Revue Russe d'Entomologie 1: 1-7.

Chistyakov, Yu. A. 1999: Lasiocampidae. — In: Ler, P. A. (ed.), [Identification book of insects of Russian Far East. V. Trichoptera and Lepidoptera. Part I: 586617]. Vladivostok. Dalnauka. [In Russian.]

Clary, D. \& Wolstenholme, D. 1985: The mitochondrial DNA molecule of Drosophila yakuba: nucleotide sequence, gene organization, and genetic code. - Journal of Molecular Evolution 22: 252-271.

Davis, E. E., French, S. \& Venette, R. C. 2005: Mini risk assessment. Siberian silk moth, Dendrolimus superans Butler [Lepidoptera: Lasiocampidae]. [www document] URL http://www.aphis.usda.gov/plant_health/plant_pest_info/pest_detection/downloads/ pra/dsuperanspra/pdf. (Accessed 30 November2007)

Dayrat, B. 2005: Towards integrative taxonomy. - Biological Journal of the Linnean Society 85: 407-415.

DeSalle, R., Egan, M. G. \& Siddall, M. 2005: The unholy trinity: taxonomy, species delimitation, and DNA barcoding. - Philosophical Transactions of the Royal Society of London B Biological Sciences 360: 19051916.

Dubatolov, V. V. \& Zolotuhin, V. V. 1992: A list of Lasiocampidae from the territory of the former USSR (Insecta, Lepidoptera). - Atalanta 23: 531-548.

Ebert, G. (ed.) 1994: Die Schmetterlinge Baden-Württembergs. Band 4. - Verlag Eugen Ulmer. Stuttgart. 535 pp.

EPPO 2002: Dendrolimus sibiricus. [www document]
URL http://www.eppo.org/QUARANTINE/Data sheets/dsdensi.html. (Accessed 3 May 2005)

EPPO 2005: Dendrolimus sibiricus and Dendrolimus superans. EPPO/OEPP Bulletin 35, 390-395.

Eversmann, E. 1844: Fauna lepidopterologica volgo-uralensis. - Typis Universitatis. Casani. 633 pp.

Freina, de J. J. \& Witt, Th. J. 1987: Die Bombyces und Sphinges der Westpalaearktis. — Verlag GmbH. München. 708 pp.

Gaede, M. 1932: Lasiocampa - Bhima. - In: Seitz, A. (ed.), Die Grosschmetterlinge der Erde. Die Palaearktischen Spinner und Schwärmer: 113-124. Supplement. Alfred Kernen, Stuttgart. 315 pp.

Gninenko, Yu. I. 2000: [Dendrolimus superans sibiricusa threat to European forests.] [In Russian.] — Lesnoe Hozyaistvo 2000, 50-51.

Gninenko, Yu. I. \& Orlinskiy, A. D. 2002: Dendrolimus sibiricus in the coniferous forests of European Russia at the beginning of the twenty-first century. - EPPO/OEPP Bulletin 32: 481-483.

Goloboff, P. 1998: NONA. Program and documentation. Published by the author, New York.

Grünberg, K. 1911: 18. Gattung Dendrolimus Germ. — In: Seitz, A. (ed.), Die Gross-Schmetterlinge der Erde. II. Band. Spinner und Schwärmer: 171-173. Alfred Kernen, Stuttgart. 479 pp.

Hurst, G. D. D. \& Jiggins, F. M. 2005: Problems with mitochondrial DNA as a marker in population phylogeographic and phylogenetic studies: the effect of inherited symbionts. - Proceedings of the Royal Society of London, series B, 272: 1525-1524.

Isaev, A. C., Khlebopros, R. G., Nedorezov, L. V., Kondakov, Yu. P., Kiselev, V. V. \& Sukhovolskiy, V. G. 2001: [Population dynamics of forest insects.] [In Russian]. - Moscow. Nauka. 374 pp.

Kaila, L. \& Ståhls, G. 2006: DNA barcodes: Evaluating the potential of COI in delimitation of closely related species of Elachista (Lepidoptera: Gelechioidea: Elachistidae) from Australia. — Zootaxa 1170: 1-26.

Kharuk, V. I., Ranson, K. J., Kozuhovskaya, A. G., Kondakov, Yu. P. \& Pestunov, I. A. 2004: NOAA/AVHRR satellite detection of Siberian silkmoth outbreaks in eastern Siberia. - International Journal of Remote Sensing 25: 5543-5556.

Kirichenko, N. I. \& Baranchikov, Yu. S. 2004: Changes of the density optimum in the ontogenesis of larvae of the Siberian moth Dendrolimus superans sibiricus (Lepidoptera, Lasiocampidae). - Entomological Review 84: 265-270.

Klun, J. A., Baranchikov, V. C., Mastro, V. C., Hijji, Y., Nicholson, J. Ragenovich, I. \& Vshivkova, T. A. 2000: A sex attractant for the Siberian moth Dendrolimus superans sibiricus (Lepidoptera: Lasiocampidae). — Journal of Entomological Science 35: 158-166.

Konefal, T. \& Karnkowski, W. 2003: The Siberian moth (Dendrolimus sibiricus Tschetv.)(Lepidoptera, Lasiocampidae) the pest subject to compulsory control possessing risk for coniferous forests in Europe. - Progress in Plant Protection 43: 727-730.

Kuznetsov, V. N. 2006: Pamyatnik sibirskomy shelkoprya- 
du (Dendrolimus sibiricus Chtvr.) na Sakhaline [The monument of Siberian moth in the Sakhalin]. - A. I. Kurentsov's Annual Memorial Meeting 17: 134-138.

Lajonquière, Y. de. 1973: Genres Dendrolimus Germar, Hoenimnema, n. gen., Cyclophragma Turner. 10e contribution a l'etude des Lasiocampides. - Annals de Societé Entomologique de France (N.S.) 9: 509592.

Lemaire, C. \& Minet, J. 1999: The Bombycoidea and their relatives. - In: Kristensen, N. P. (ed.), Lepidoptera, moths and butterflies:. 321-353. Vol. I. Evolution, systematics and biogeography. Walter de Gruyter. Berlin.

Linnaeus, C. 1758: Systema Naturae. Ed. X. — Stockholm.

Maeto, K. 1991: Outbreaks of Dendrolimus superans (Butler) (Lepidoptera: Lasiocampidae) related to weather in Hokkaido. - Applied Entomology and Zoology 26: 275-277.

Marttila, O., Saarinen, K., Haahtela, T. \& Pajari, M. 1996: [The Finnish hawk moths and bombycids, with Notodontidae, Lymantriidae and Arctiidae] (in Finnish with English summaries). Kirjayhtymä. Helsinki. 384 pp.

Matsumura, S. 1925: On the three species of Dendrolimus which attack spruce and fir trees in Japan, with their parasites and predaceous insects. - Annals of Zoological Institute of the Academy of Sciences USSR 26: 27-50.

Mengual, X., Ståhls, G., Vujic, A. \& Marcos-Garcia, M. A. 2006: Integrative taxonomy of Iberian Merodon species (Diptera, Syrphidae). — Zootaxa 1377: 1-26.

Mikkola, K. 2007: The rise of eversion techniques in lepidopteran taxonomy (Insecta: Lepidoptera). — SHILAP Revista de lepidopterologia 35: 335-345.

Mikkola, K. 2008: The lock-and-key mechanisms of the internal genitalia of the Noctuidae (Lepidoptera): How are they selected for? - European Journal of Entomology 105: 13-25.

Milankov, V., Ståhls, G., Stamenkovic, J. \& Vujic, A. 2008: Genetic diversity of populations of Merodon aureus and $M$. cinereus species complexes (Diptera, Syrphidae): integrative taxonomy and implications for conservation priorities on the Balkan Peninsula. Conservation Genetics. doi: 10.2007/s10592-0079426-8.

Möller, K. 2005: Der Kiefernspinner, Dendrolimus pini L. — Faltblatt der Landesforstanstalt. [www document] URL http://www.eppo.org/QUARANTINE/insects/Dendrolimus_sibiricus/DS_Dendrolimus_spp.pdf. (Accessed 30 November 2007)

Nieminen, M. (ed.) 1996: International moth monitoring scheme - proceedings of a seminar. - TemaNord 1996: 630, 75 pp.

Nixon, K. C. 1999: Winclada (BETA) ver. 0.9.9. Published by the author, Ithaca, New York.

Orlinskiy, A. D. 2000: EXFOR Database pest report: Dendrolimus sibiricus Tschetwerikov. — USDA Forest
Service. [www document] URL http://www.aphis.usda.gov/plant_health/plant pest_info/pest_detection/ downloads/pra/dsuperanspra.pdf. (Accessed 30 November 2007)

Petersen, W. 1905: Predvaritelniy otchet o puteshetviy dlya izucheniya Lepidoptera y ykh rasprostraneniya po Uralskomu khrebty v 1903 g. - Izvestiya Russkogo Geografichekogo Obshestva 40: 631-634.

Pletniev, V. A., Vendiilo, N. V., Ponomariev, V. L., Mitroshin, D. B. \& Lebedyeva, K. B. 1999: The search for a pheromone of Dendrolimus sibiricus. - In: Gninenko, Yu. I., Liamtsev, N. I. \& Ferbikov, V. A. (eds), Protection of taiga forests of Siberia against Dendrolimus sibiricus: 56-57. Proc. Scientific-Practical Seminar, Gorno-Altaisk 19-21 July 1999. [in Russian].

Roe, A. D. \& Sperling, F. A. H. 2007: Patterns of evolution of mitochondrial cytochrome c oxidase I and II and implications for DNA barcoding. - Molecular Phylogenetics and Evolution 44: 325-345.

Rougeot, P.-C. \& Viette, P. 1980: Svärmare och spinnare i Europa och Nordafrika (Swedish translation: B. Gustafsson). Albert Bonniers Förlag. Stockholm.

Rubinoff, D. 2006: Utility of Mitochondrial DNA Barcodes in Species Conservation. - Conservation Biology 20: $1548-1549$

Saalas, U. 1949: Suomen metsähyönteiset sekä muut metsälle vahingolliset ja hyödylliset eläimet. WSOY, Porvoo. pp 719.

Simon, C., Frati, F., Beckenbach, A., Crespi, B., Liu, H. \& Flook, P., 1994: Evolution, weighting and phylogenetic utility of mitochondrial gene-sequences and a compilation of conserved polymerase chain-reaction primers. - Annals of the Entomological Society of America 87: 651-701.

Smith, M. A., Wood, D. M., Janzen, D. H., Hallwachs, W. \& Hebert, P. D. N. 2007: DNA barcodes affirm that 16 species of apparently generalist tropical parasitoid flies (Diptera, Tachinidae) are not all generalists. - Proceedings of the National Academy of Science 104: 4967-4972.

Vogler, A. P. \& Monaghan, M. T. 2007: Recent advances in DNA taxonomy. - Journal of Zoological Systematics and Evolutionary Research 45: 1-10. doi: 10.1111/ j1439-0469.

Wellenstein, G. 1978: Dendrolimus Germar. Die Forstschädlinge Europas. 3. Band. Schmetterlinge: 435444. Verlag Paul Parey. Hamburg und Berlin. 467 pp.

Zhang, A., Kong, X., Li, D. \& Liu, Y. 2004: DNA fingerprinting evidence for the phylogenetic relationship of eight species and subspecies of Dendrolimus (Lepidoptera: Lasiocampidae) in China. - Acta Entomologica Sinica 47: 236-242.

Zolotuhin, V. V. 1995: An annotated checklist of the Lasiocampidae of Kazakhstan and Middle Asia. - Atalanta 26: 273-290.

Økland, B., Kvamme, T. \& Thunes, K. 2004: Tømmerimport og innføring av insekter. - Glimt fra skogforskningen 2004, 2 pp. [In Norwegian.] 